\title{
واقع الحرية في الحضارات القديمة ومنطلقات ممارستها في المجتمعات الإسلامية المعاصرة (The Reality of Freedom in Past Civilizations and Its Practices in Contemporary Islamic Societies)
}

Amer Abdulwahab Mahyoub Murshed* \& Eftekhar Ali Abdo Amer**

\section{الملخص}

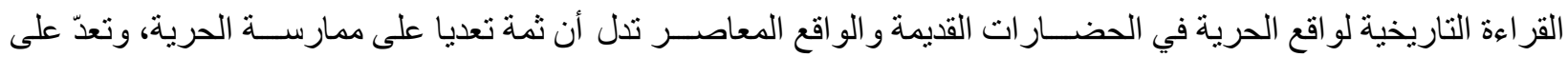

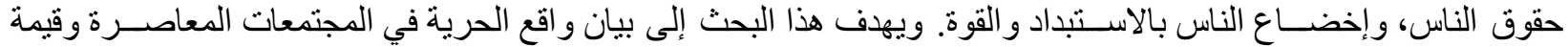

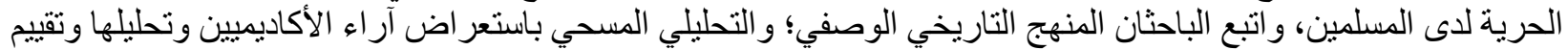

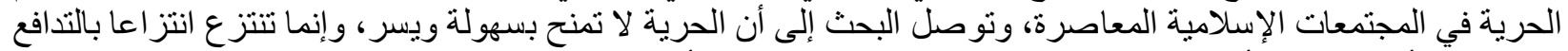

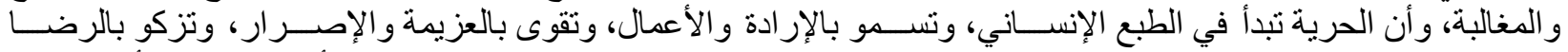

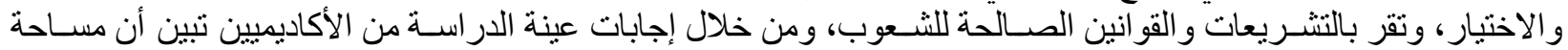

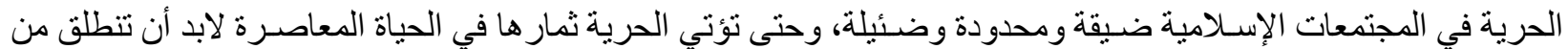

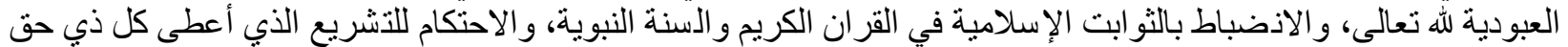
حقه؛ بلا تفاضل و لا استثناء.

$$
\text { الكلمات المفتاحية: الحرية، الواقع، الحضار ات، المنطلقات، المجتمعات المعاصرة. }
$$

\begin{abstract}
Historical reading of the actual picture of freedom in ancient civilizations and today's realities indicates that the values of freedom and human rights have been violated. It also indicates that people have been subjugated by authoritarian regimes. The purpose of this research is to reflect on the actual reality of freedom in contemporary Islamic societies. To this effect, the study adopted a descriptive and historical approach using a survey to review the opinions of academics about freedom in contemporary Islamic societies. The study suggests that freedom is not granted easily but is rather obtained by force. It also indicates that freedom is inherent in human nature and it is often enhanced by persistence, enriched by satisfaction, and prescribed by good legislations. The opinions obtained by the survey also suggest that there exists an utterly insignificant and limited space of freedom in Islamic societies. To yield fruitful results in our contemporary life, freedom must be originated from the servitude to the Almighty Allah by adhering to the Islamic constants in the Quran and Prophetic traditions and referring to Islamic legislation in which all rights are protected without favor nor exception.
\end{abstract}

Keywords: Freedom, principles, reality, civilizations, contemporary Islamic societies

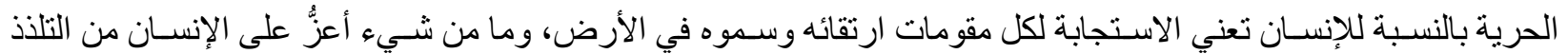

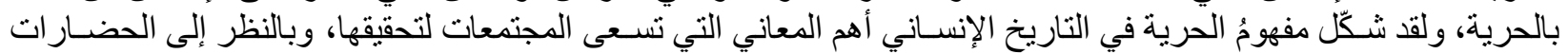

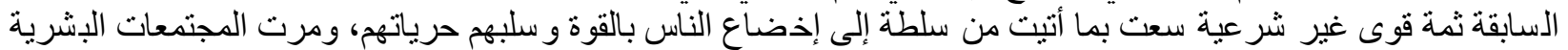

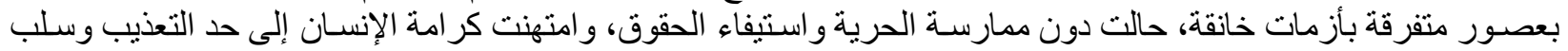
الإر ادة و التمايز بين البشر حسب السلالة و المال و المنصب.

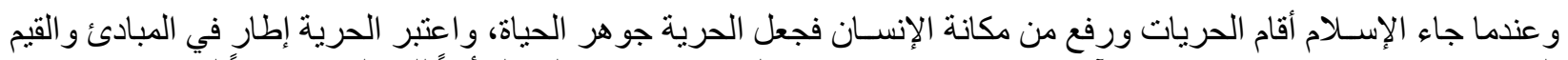

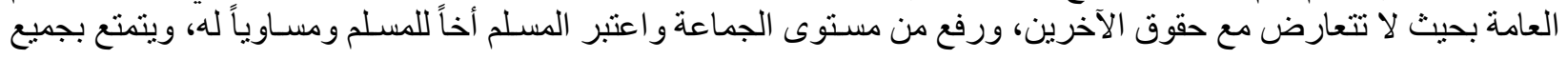

\footnotetext{
* Amer Abdulwahab Mahyoub Murshed (Ph.D), Senior Lecturer, Department of Siyasah Syariyyah, Academy of Islamic Studies, University of Malaya, 50603 Kuala Lumpur, Malaysia. Email: almurshed@um.edu.my.

** Eftekhar Ali Abdo Amer, Manager of Ayat Institute for Quranic Education, Pearl Avenue, Jalan Sepakat indah 3, Sungai chua, 43000 Kajang, Selangor.
} 
Journal of Al-Tamaddun, Vol. 16 (2), 2021, 111-126

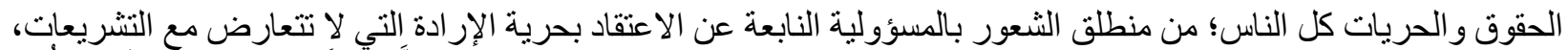

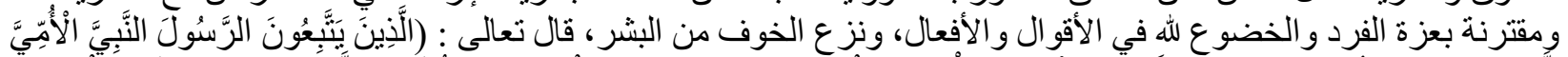

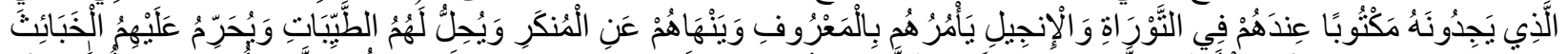

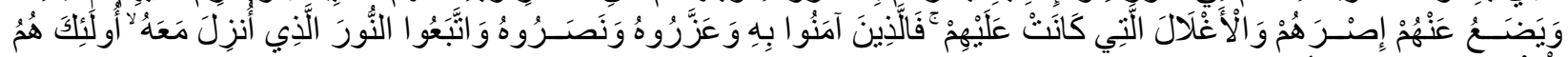

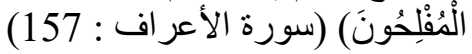

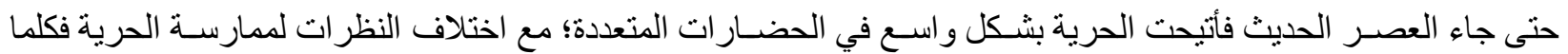

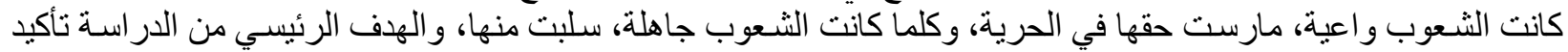

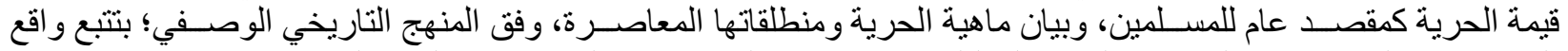

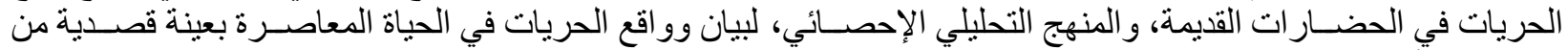

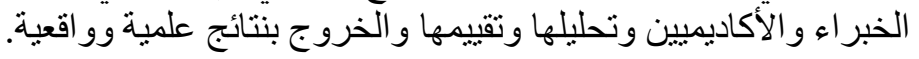

وقد تبين للباحثين من خلال النظر في الاراسات السابقة، أن ثمة دراسات تناولت الحرية بزو ايا مختلفة منها: در اسة " تأسيس

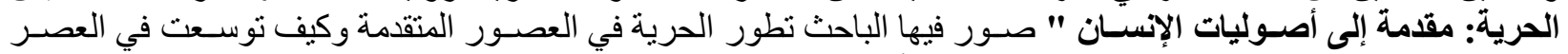

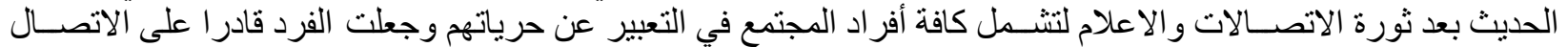

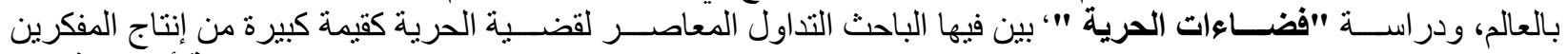

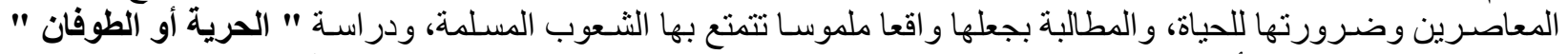

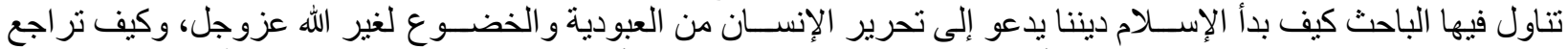

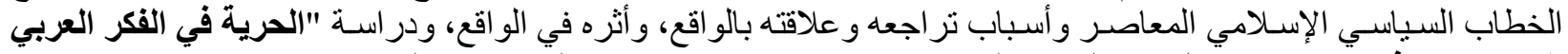

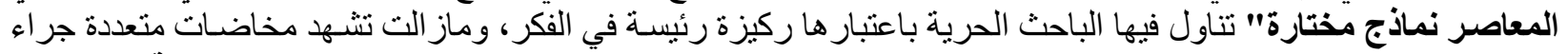

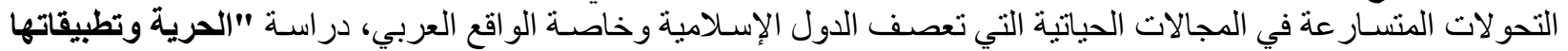

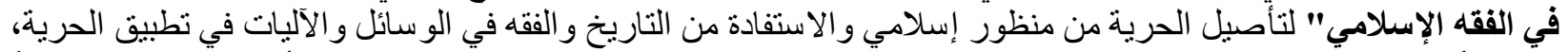

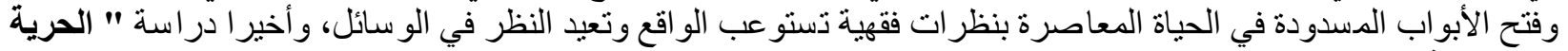

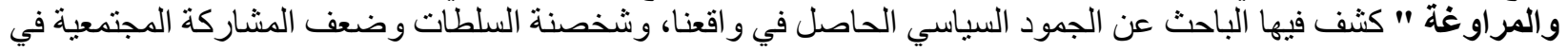

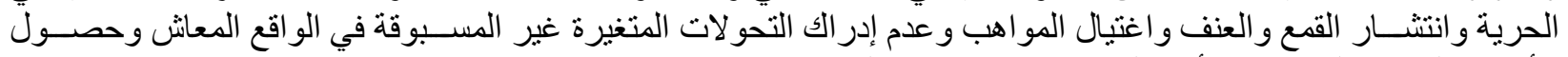

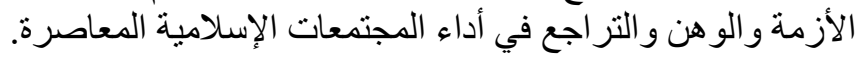

\section{المبحث الأول: تعريف الحرية لغةً واصطلاحا}

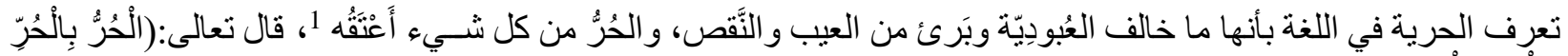

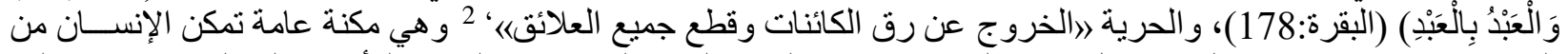

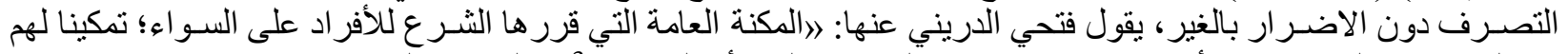

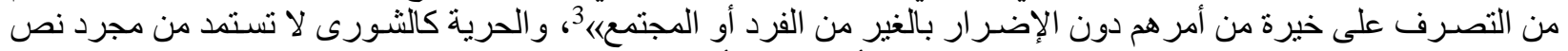

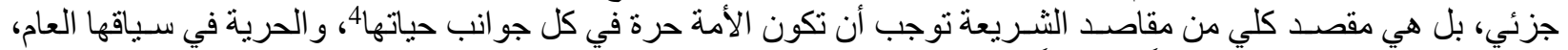

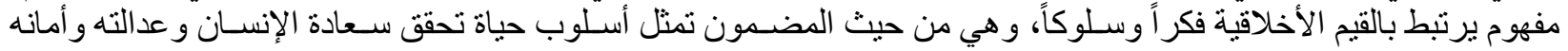

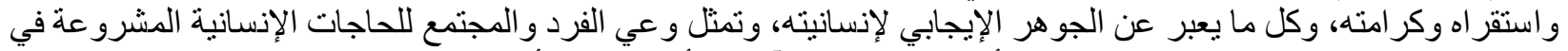

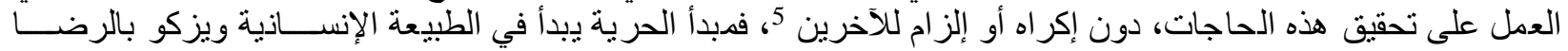

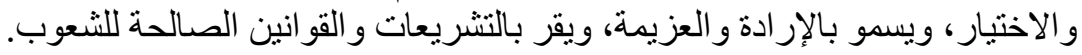

و الذي يترجح في تعريف الحرية أنها: "مقصد و اجب في العمل السياسي، تمكن الفرد و الجماعة من المشاركة، وحرية الاختبار

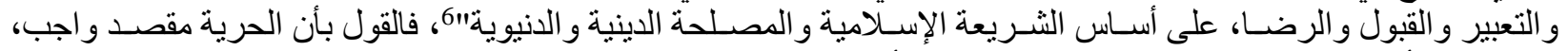

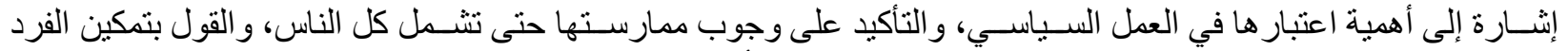
و الجماعة فيه إثـــارة إلى تســـيل ممارســتها على الجماعات و الأفر اد في المحيط الإســلامي، و القول بحرية الاختيار و القبول الفيل

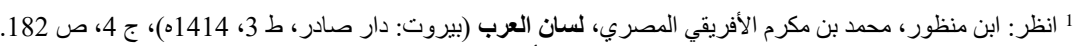

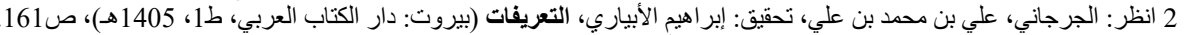

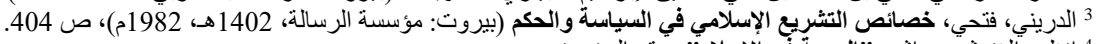
4 انظر : الغنوشي، راثد. "الحرية في الإسلام" موقع الجزيرة.

https://www.aljazeera.net/knowledgegate/opinions/2007/10/11

5 انظر: عويّد، عدنان، الحرية وعي الضرورة (صحيفة المثقف، العدد: 4706 المصادف: الخميس 25 - 07 - 2019م. 6 عامر ، عبد الو هاب، الحرية السياسية في الثريعة الإسلامية دراسة مقارنة بالقانون الدولي، (ماليزيا: رسالة دكتور اة الجامعة الإسلامية العالمية 2012م)، ص 26. 
واقع الحرية في الحضارات القديمة ومنطلقات ممارستها في المجتمعات الإسلامية المعاصرة

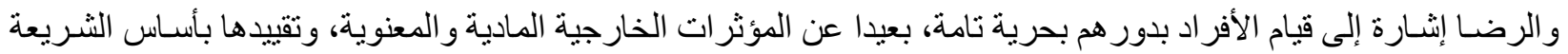

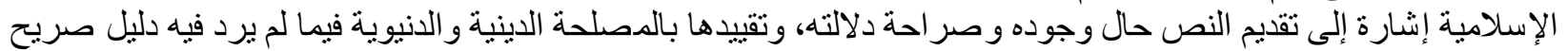

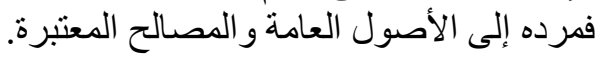

\section{المبحث الثاني: واقع الحرية في تاريخ الحضارات القديمة}

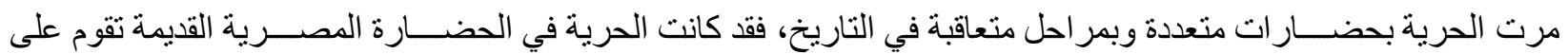

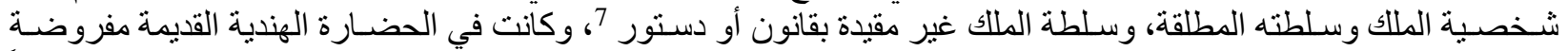

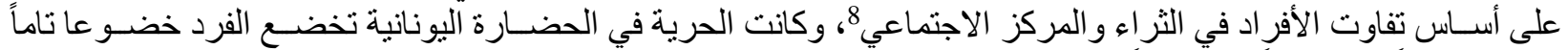

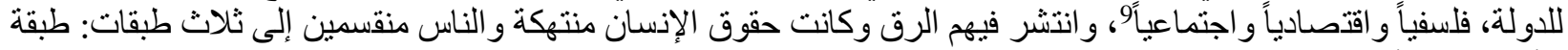

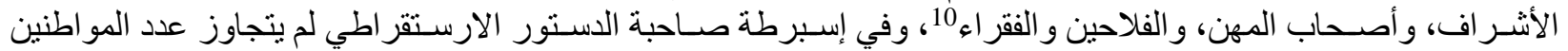

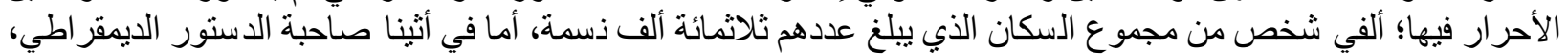

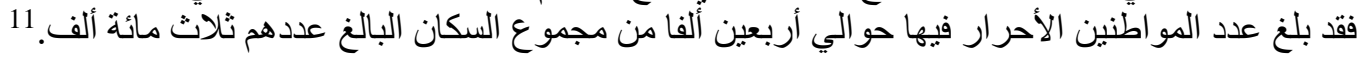

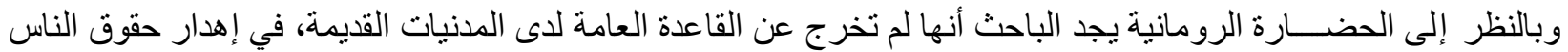

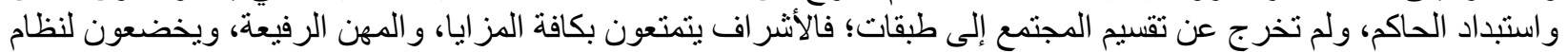

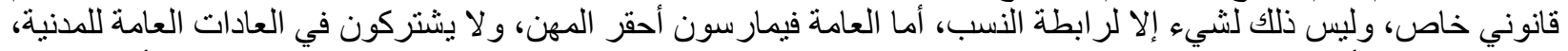

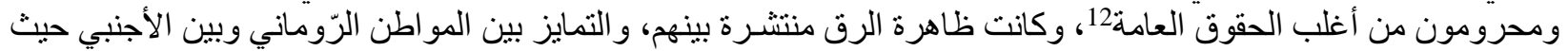

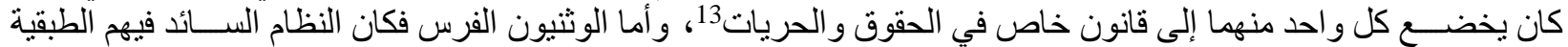

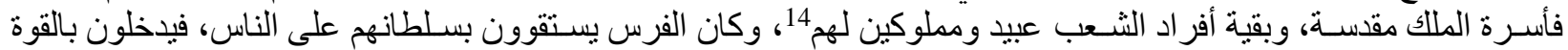

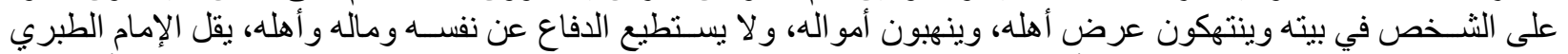

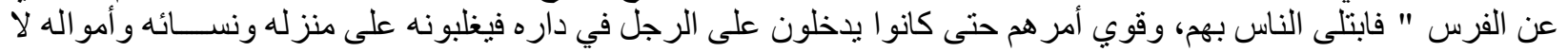

يستطيع الامتناع منهم".

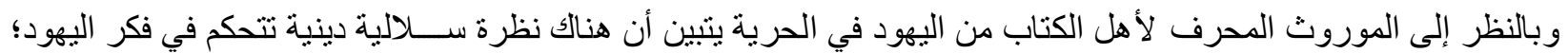

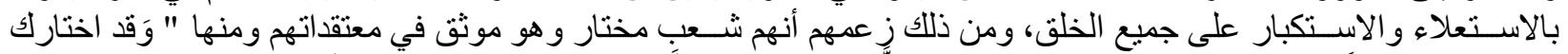

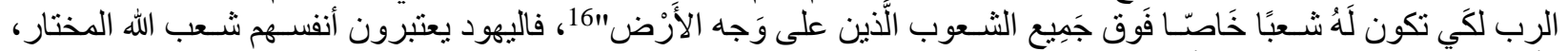

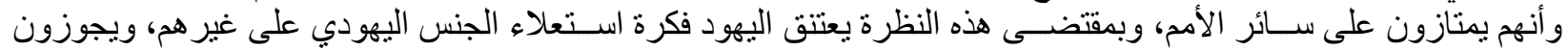

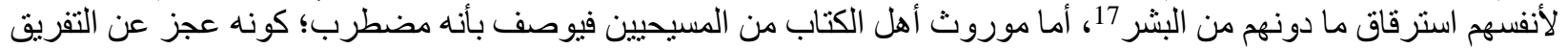

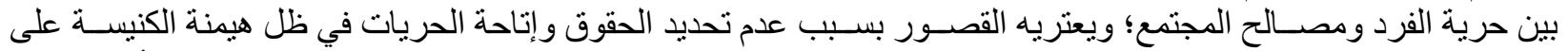

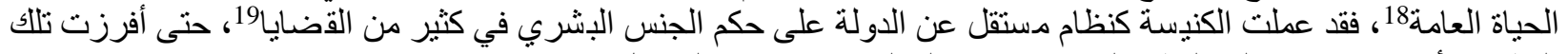

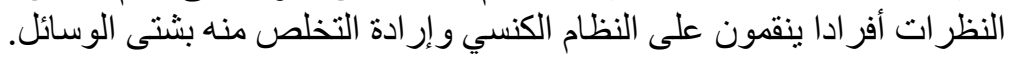

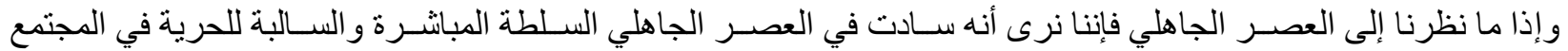

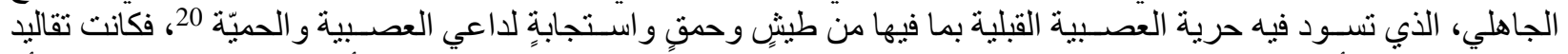

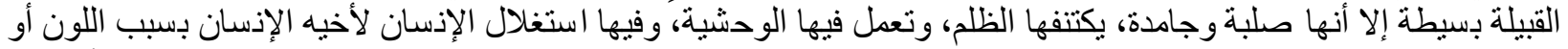

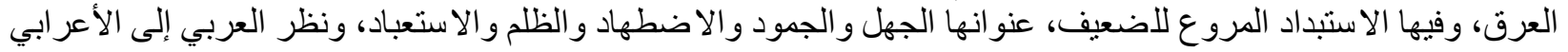

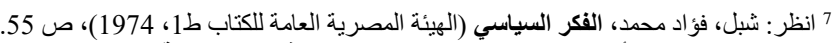
8 انظر: بدوي، ثروت، أصول الفكر السياسي والنظريات والدذاهب السياسية الكبرى (القاهرة: دار النهضة العربية، 1970م)، ص13.

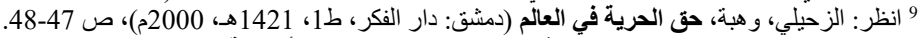

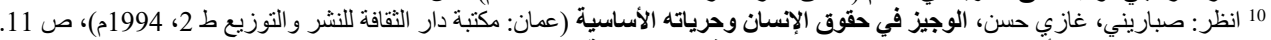

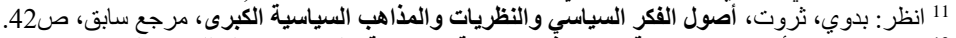

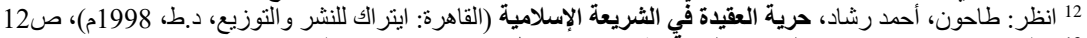

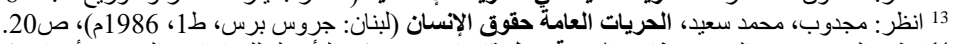

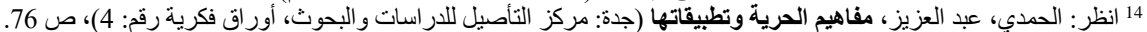

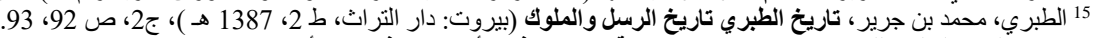

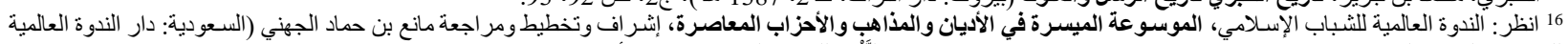

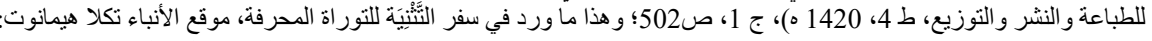
https://st-takla.org/Bibles/BibleSearch/showVerses.php?book=5\&chapter=14\&vmin=2\&vmax=2

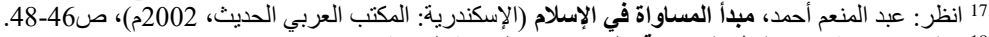

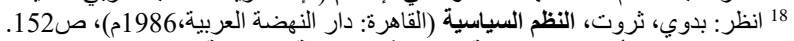

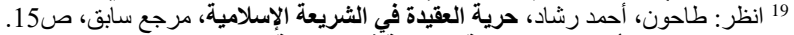
20 انظر : الثريف، أحمد إبر اهيم، مكة و المدينة في الجاهلية وعهذ الرسول صلية صلى الله عليه وسلم (دار الفكر العربي)، ص 84. 
Journal of Al-Tamaddun, Vol. 16 (2), 2021, 111-126

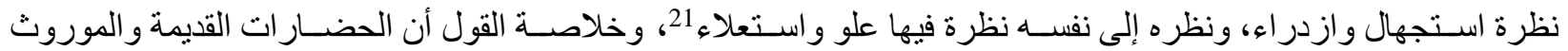

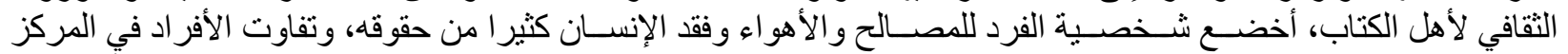

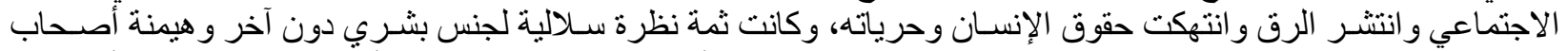

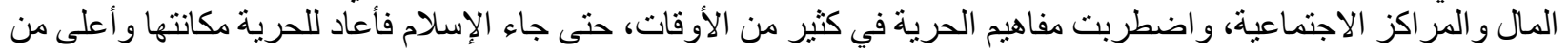

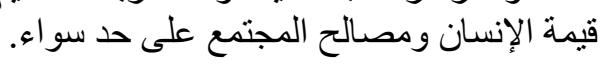

\section{المبحث الثالث: واقع الحرية بعد ظهور الإسلام}

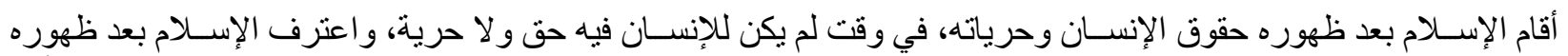

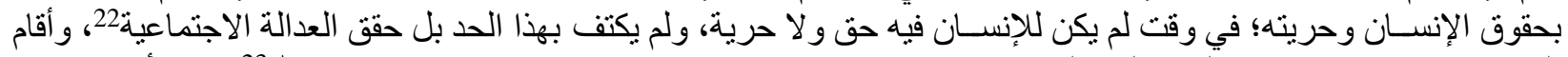

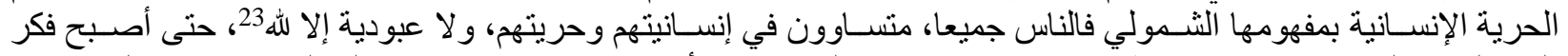

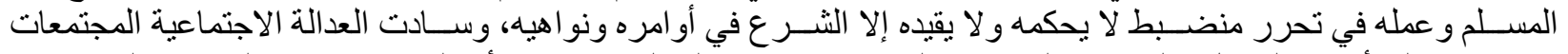

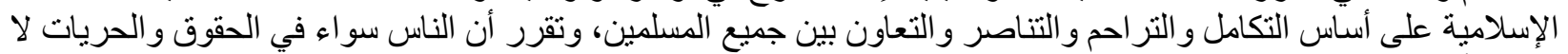

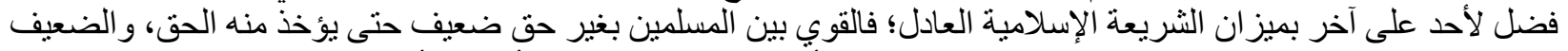

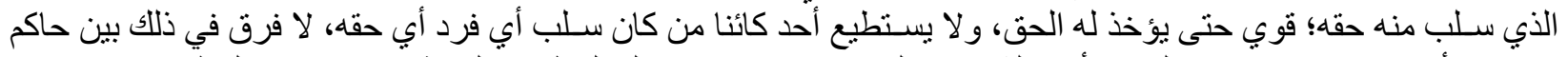

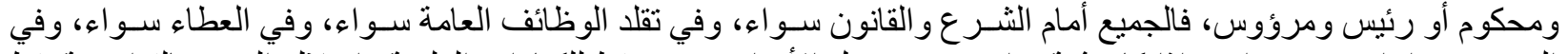

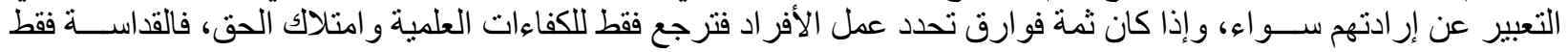
للحقوق و القو انين وليست للمنازل و المكانات، وبهذا طبع الإسلام المسلمين على المساو اة في حصو لهانم على حرياتهم وحقوقهم.

و أقام الإسلام الحرية تباعاً لضو ابط التشريع الإسلامي المعتمدة على القرآن الكريم و السنة النبوية المطهرة؛ فالحرية لها ألها أهداف

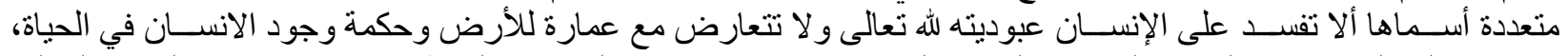

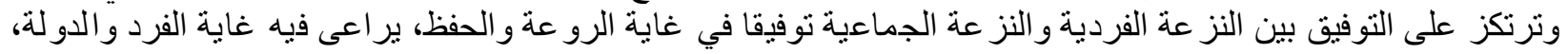

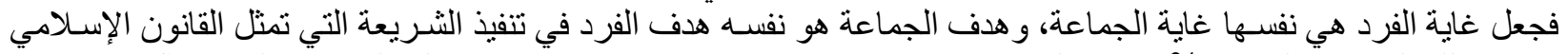

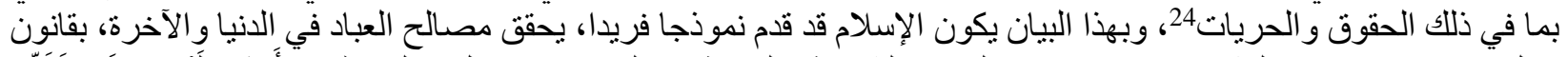

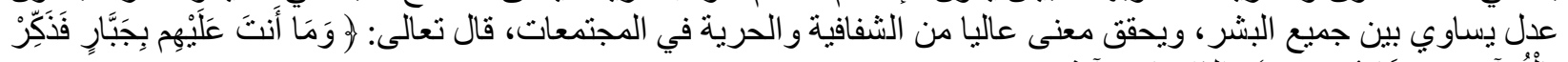

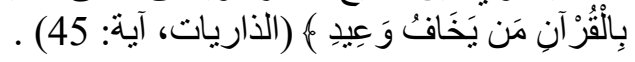

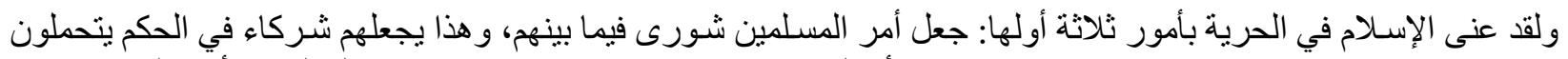

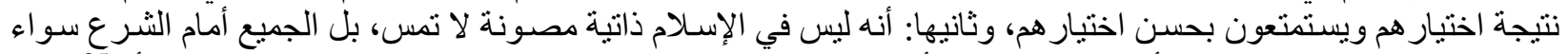

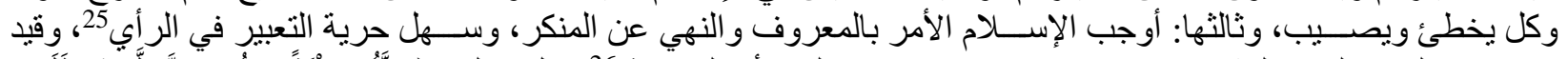

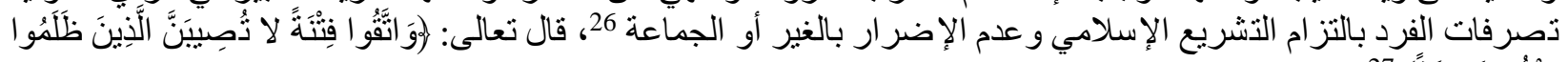

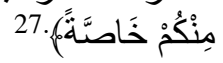

وبهذا أقام الإسـام دولته القانونية فأعطى للحرية مفهوماً يغاير المفاهيم التي كانت سـائدة في الأزمنة السـابقة، من ظلم والم واستبداد

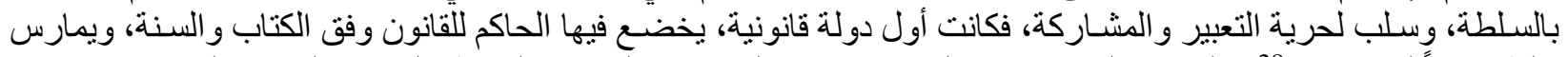

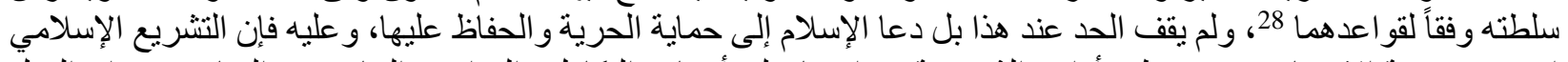

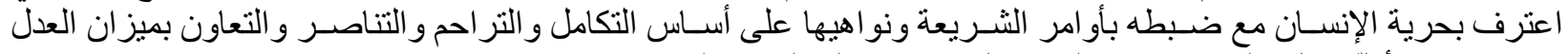

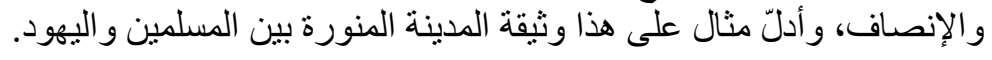

فوثيقة المدينة تعد أول وثيقة دستورية كتب فيها الر سول الله ـ صلى الله عليه و سلم- كتاباً بين المهاجرين و الأنصار ، وو ادع فيها

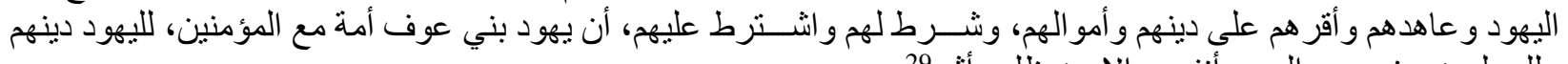

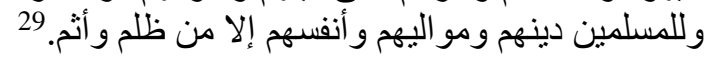

21 انظر: جواد علي، المفصل في تاريخ العرب قبل الإسلام (دار الساقي، ط4، 1422هـ، 2001م)، ج7، 292.

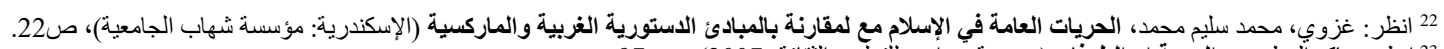

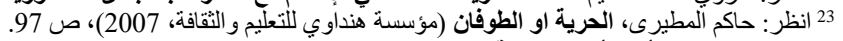

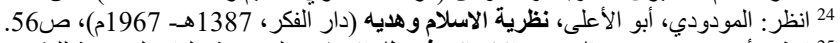

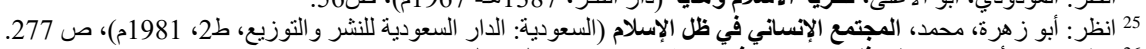

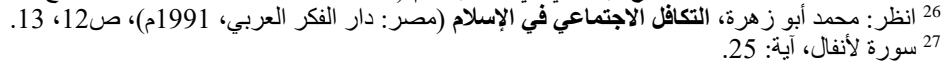

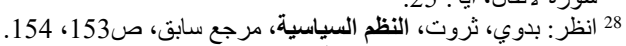

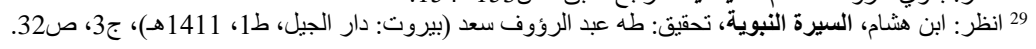




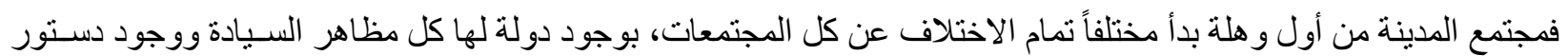

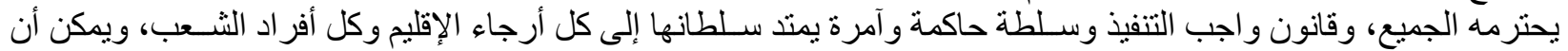

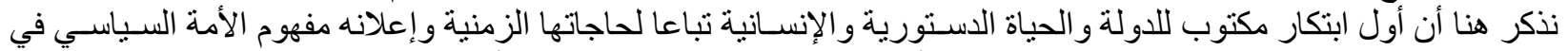

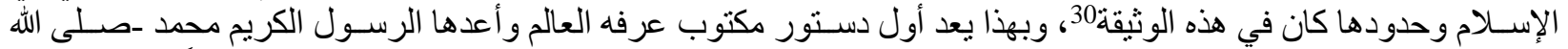

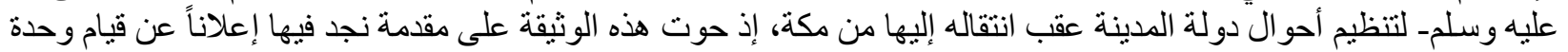

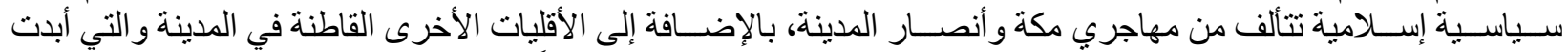

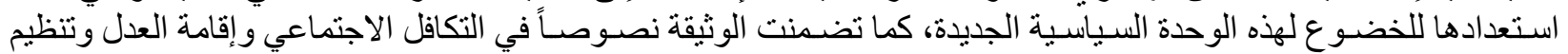

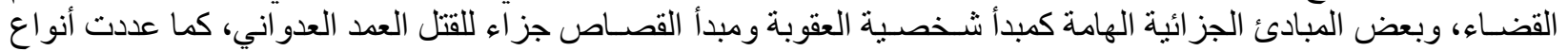

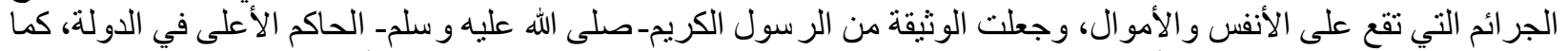

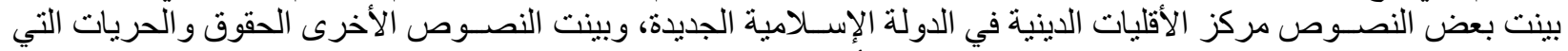

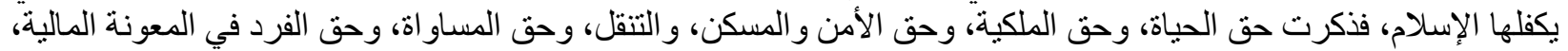

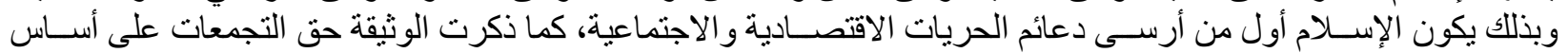

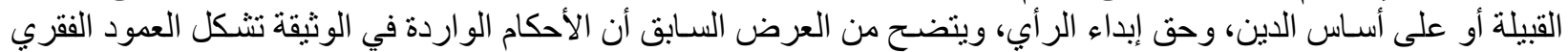

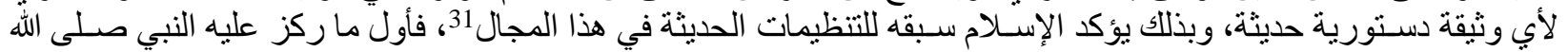

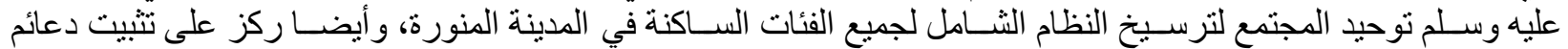
الاستقرار الذي يقوم على التعاون والاجتماع وحماية المصالح المشنتركة.

وبهذا يكون الإسـلام أول من أرسى مبدأ خضوع الدولة للقانون وهو المبدأ التي تفر عت عنه الفلسفة الحديثة لحقوق الإنسـان في

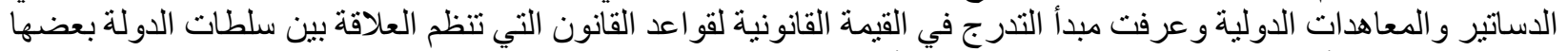

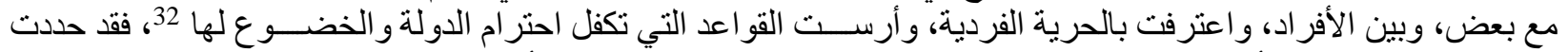

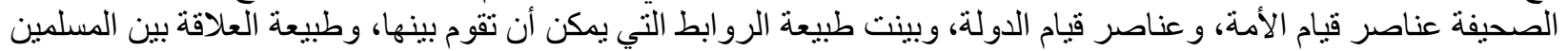

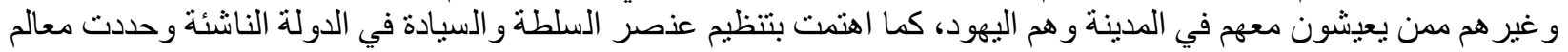
هذه السيادة.

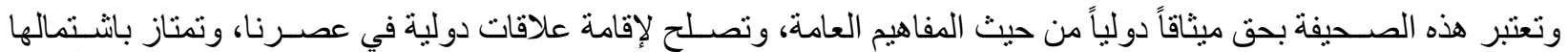

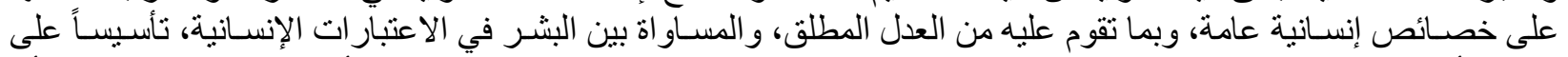

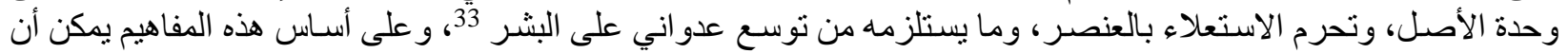

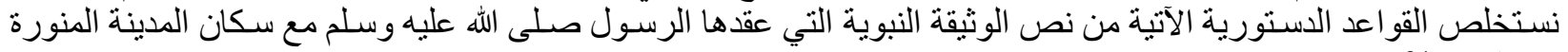
من اليهود

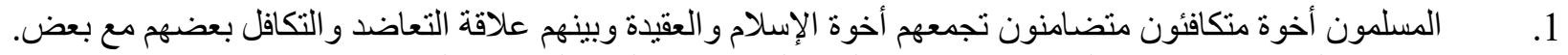

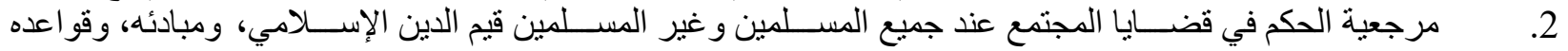
الاجتماعية، و السياسية. 3. التهاقدة والاتفاق و الاجتماع على الخير بين المسلمين و غير هم وليس على الإثم و الظلم و العدوان.

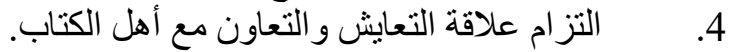
5. التز ام جميع الأطر اف بالعقد وحماية الأرض.

\section{المبحث الرابع: واقع الحرية في العصور الوسطى}

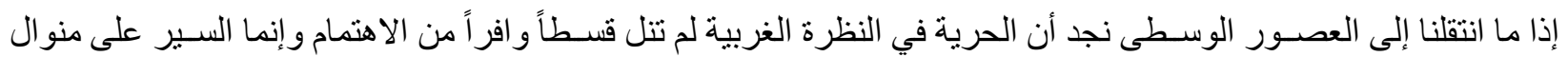

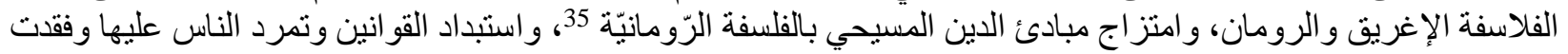

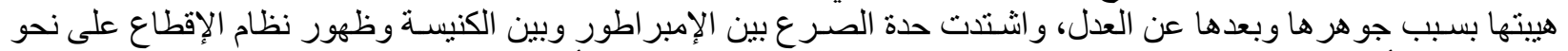

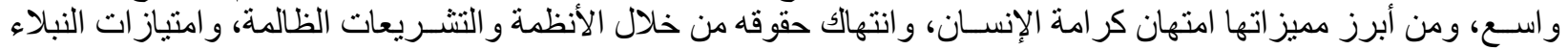

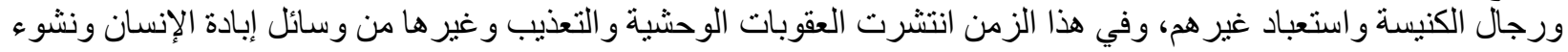

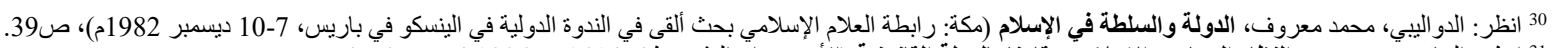

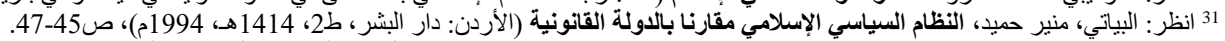

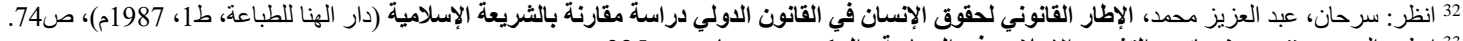

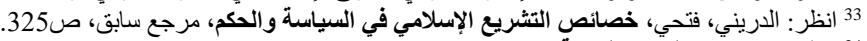

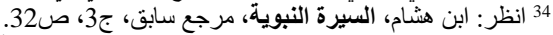
35 انظر: الجبوري، ساجر ناصر حمد. حقوق الإنسان السياسية في الإسلام والنظم العالمية (بيروت: دار الكتب العلمية ط1، 1426هـ، 2005م). ص31. 


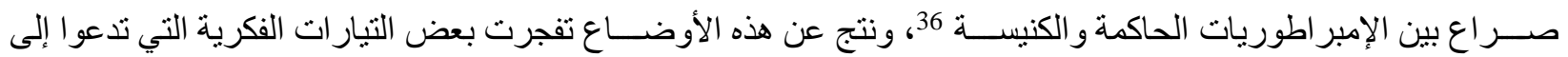

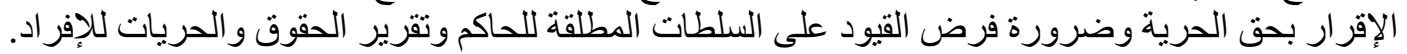

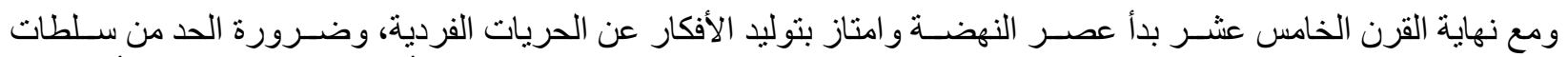

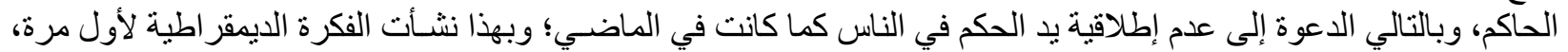

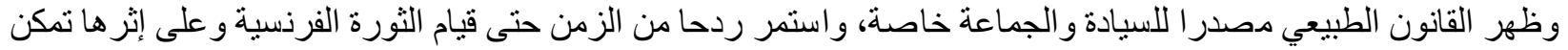

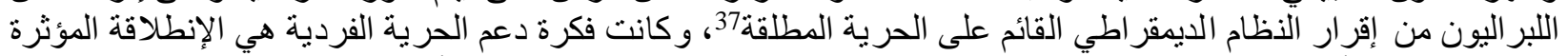

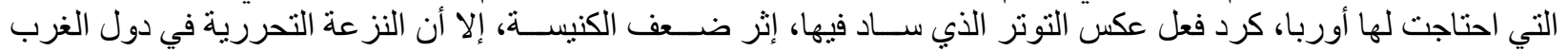

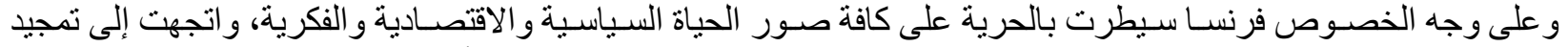

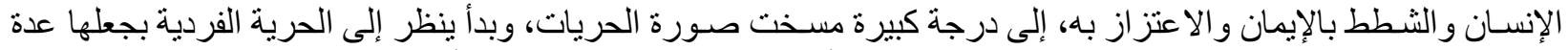

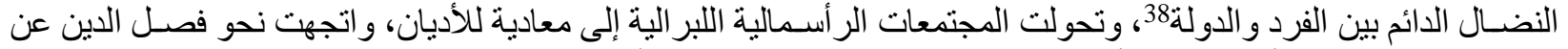

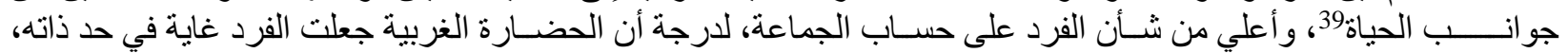

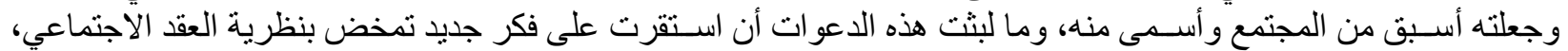

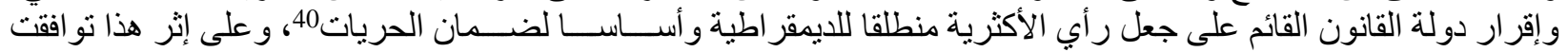

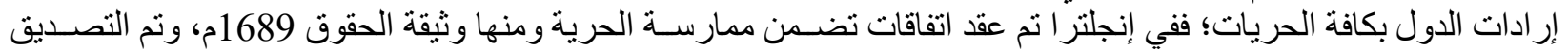

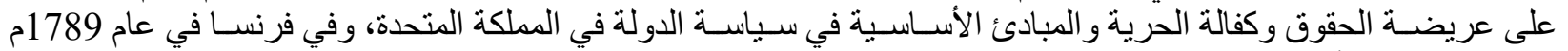

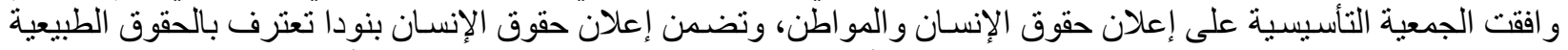

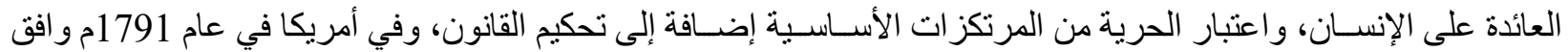

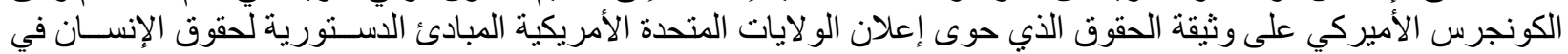

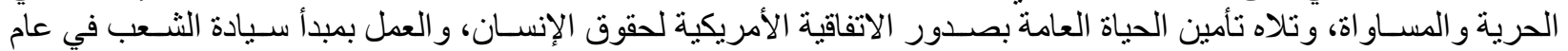

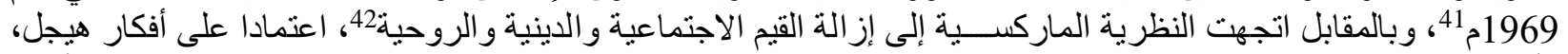

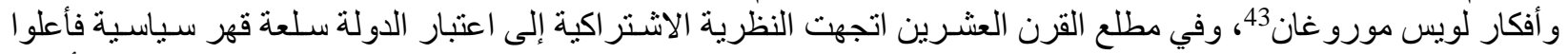

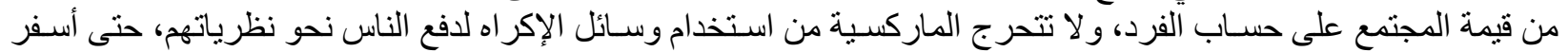

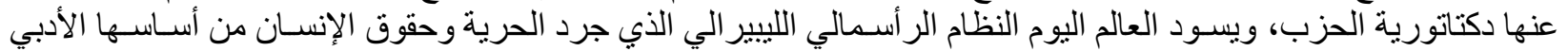

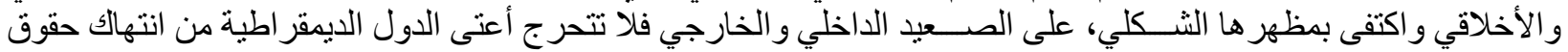
الإنسان خدمة لمصالحها.

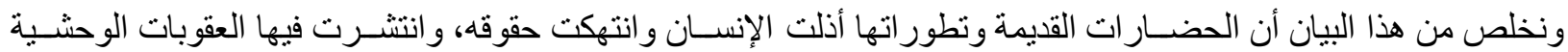

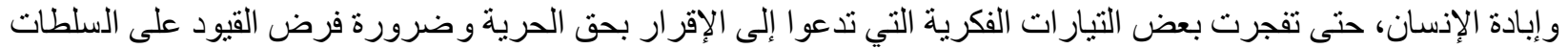

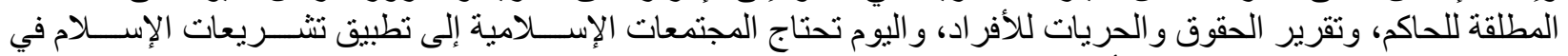
ممارسة الحرية المنضبطة بالقيم و الأخلاق و التشريعات للافرات الإسلامية.

\section{المبحث الخامس: منطلقات الحرية في المجتمعات الإسلامية المعاصرة}

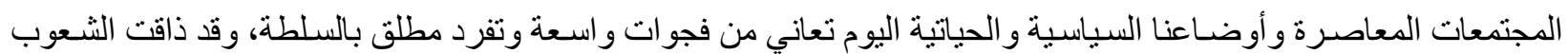

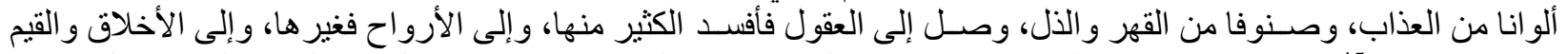

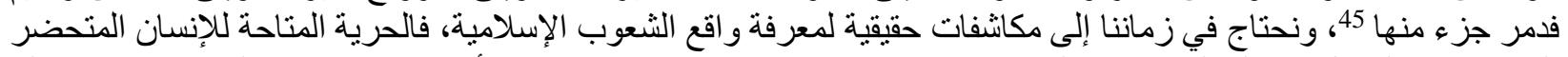

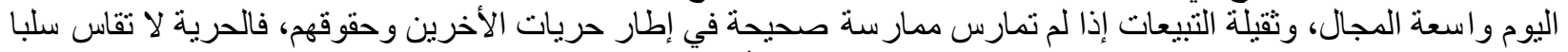

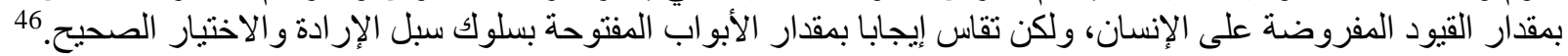

(النظر: الحقيل، سليمان، حقوق الإنسان في الإسلام والرد على الثبهات المثارة حوله (الرياض ط2)، ص212-22-21، ومحمد أحمد عطية، حقوق الإنسان بين هدي الرحمن واجتهاد الإنسان

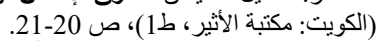

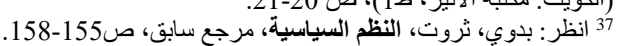

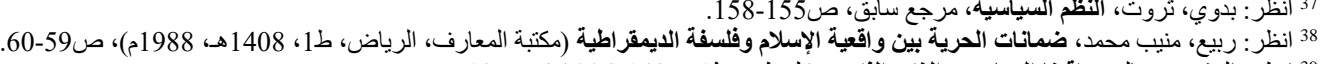

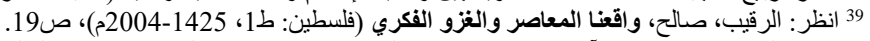

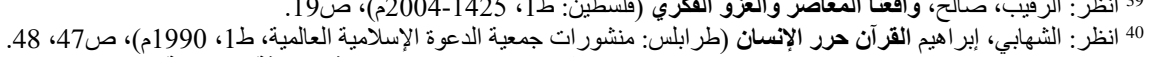
41 انظر: المنظومة الدولية لحقوق الانسان و القانون الدولي، الحق قديم وثثائق حقوق الإنسان في الإنقافة الإسلامية، تحليل وتقديم غانم جو اد. http://www.iohril.org/news.php?extend.304.6.

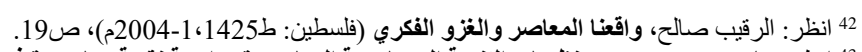

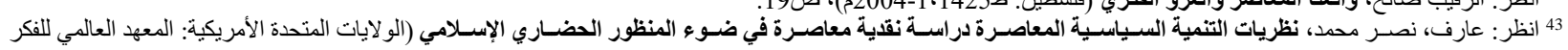

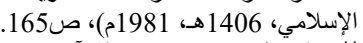

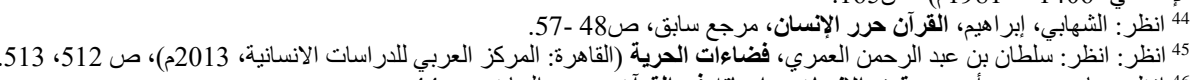

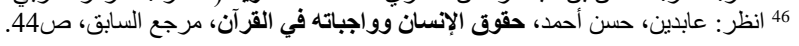


واقع الحرية في الحضارات القديمة ومنطلقات ممارستها في المجتمعات الإسلامية المعاصرة

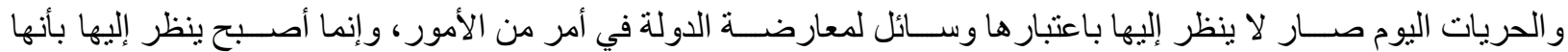

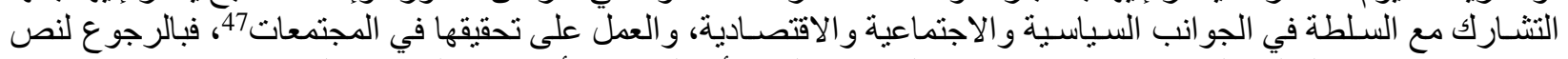

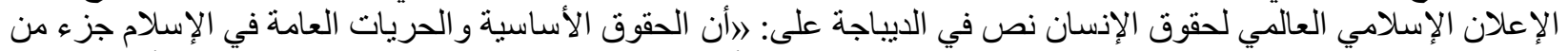

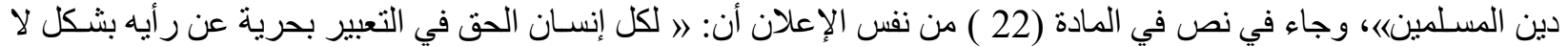

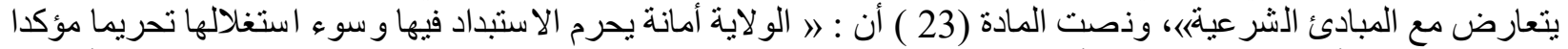

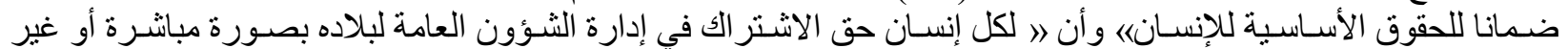

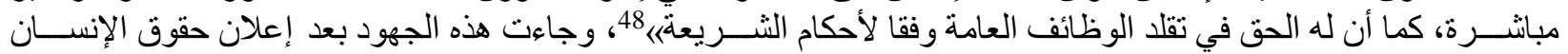

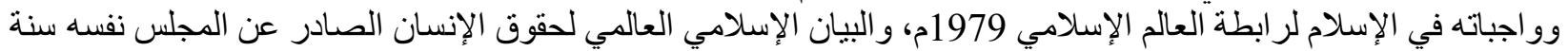

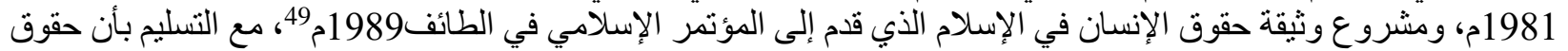

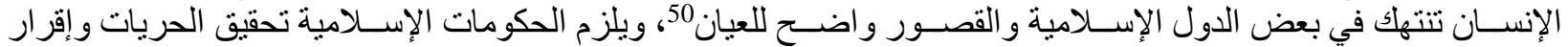
المشاركات وفقا للاساتير و القو انين و المو اثثق و المعاهدات الدولية التي تطالب بحق الإنسان الإنسان في الحرية.

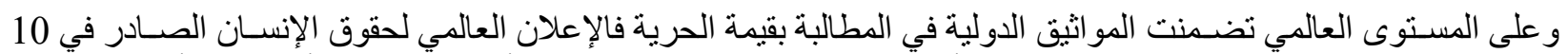

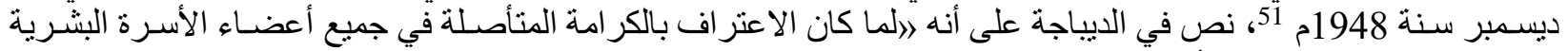

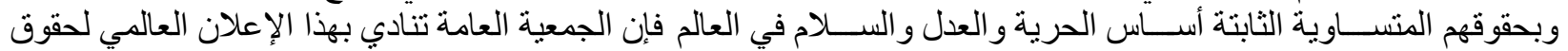

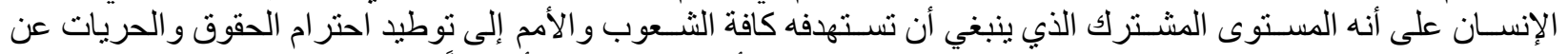

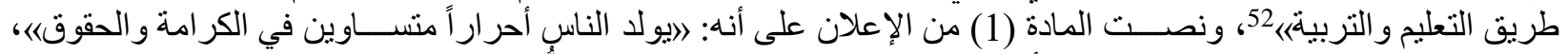

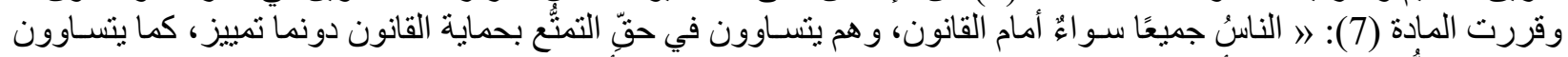

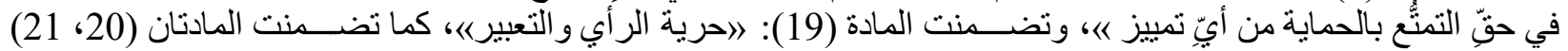
الحقوق و الحريات السياسية:

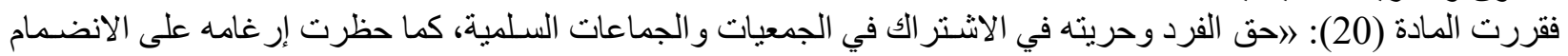
إلى جمعية بعينهاها.

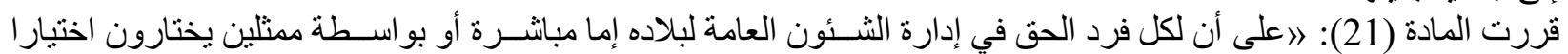

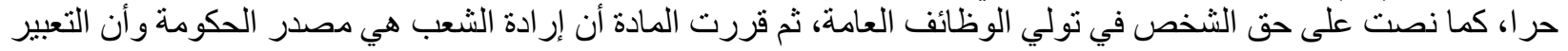
عن هذه الإر ادة يكون بانتخابات نزيهةتًا.

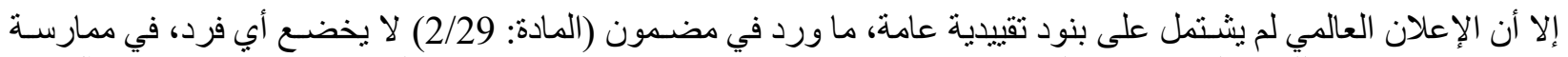

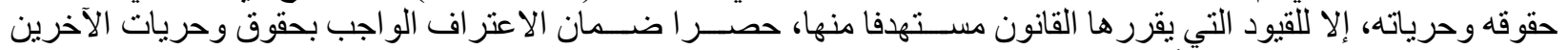

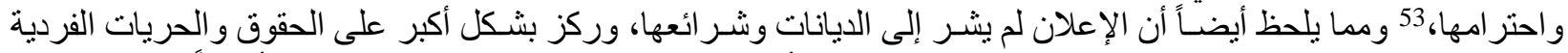

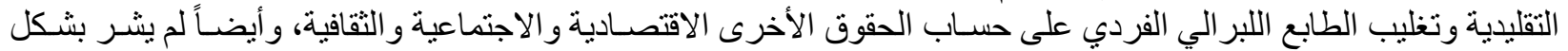

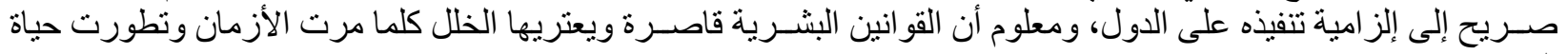

\section{المبحث السادس: الدراسة التطبيقية لمنطلقات الحرية في المجتمعات الإسلامية المعاصرة}

جاءت إجابات عينة الدر اسة من الخبر اء حول أسئلة الدراسة في صورة تفصيلية، كما تقتضيه طبيعة المقابلات ذات الأسئلة شبه

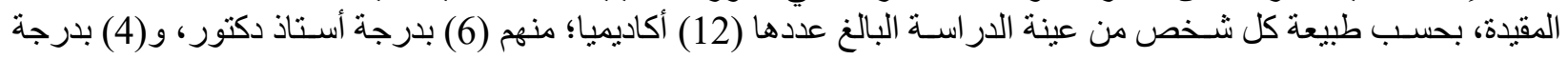
دكتور ، و(2) بدرجة ماجستير.

وبعد التحليل و الفرز و التصنيف من الباحث في الإجابات بالنظر إلى الجانب العملي و العلمي كانت إجابات عينة الدراسة بالآتي:

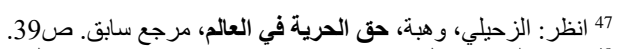

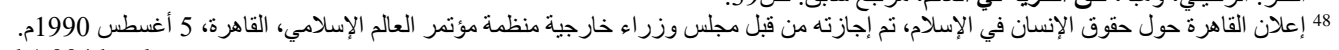
http://hrlibrary.umn.edu/arab/a004.html.

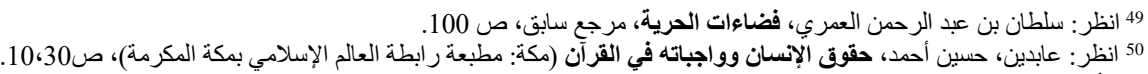

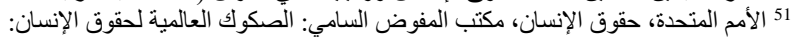
https://www.ohchr.org/ar/ProfessionalInterest/Pages/UniversalHumanRightsInstruments.aspx.

52 الأمم المتحدة، الإعلان العالمي لحقوق الإنسان: https://www.un.org/ar/universal-declaration-human-rights/index.html.

53 انظر: الأمم المتحدة، حقوق الإنسان، مكتب المفوض السامي: الصكوك العالمية لحقوق الإنسان: https://www.ohchr.org/ar/ProfessionalInterest/Pages/UniversalHumanRightsInstruments.aspx. 
السؤال الأول: هل ترى أن الحرية متاحة في المجتمعات الإسلامية؟

\begin{tabular}{|c|c|c|c|c|}
\hline 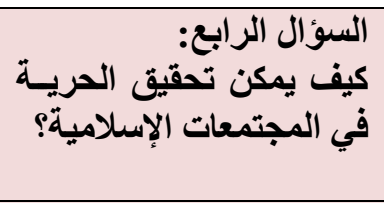 & 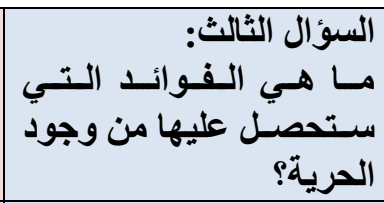 & 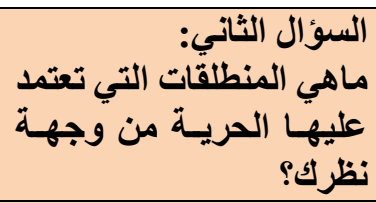 & 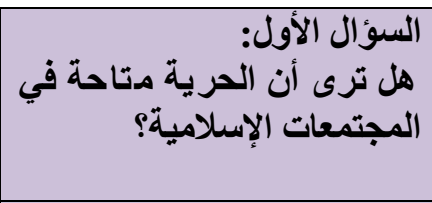 & الاستبانة \\
\hline 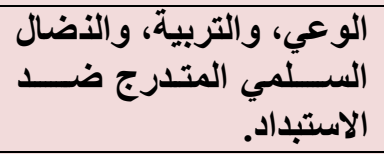 & والإرادة والكر امـة، والعدالة، والابتكار. & 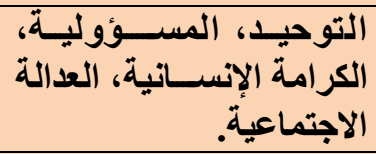 & ضئيا & 1 \\
\hline بوجود دولة القانون. & والاســـتقرار، والتــأهيـلـ، & شرعية وقانونية وعرفية. & متاح & 2 \\
\hline 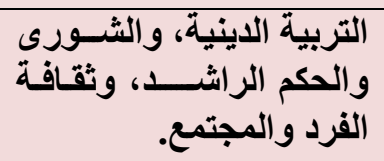 & التغييز والتطور وتحقيق الخلافة. & 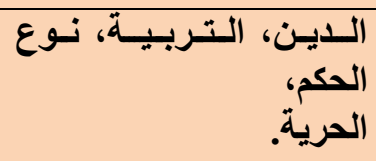 & والقتلف بـاختلاف المجتمعـات & 3 \\
\hline 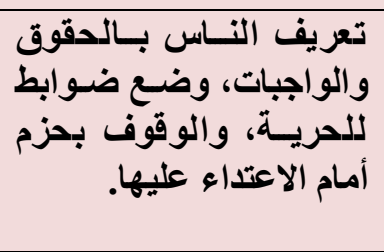 & رضشر. البــا لله تعالى، وســعادة & 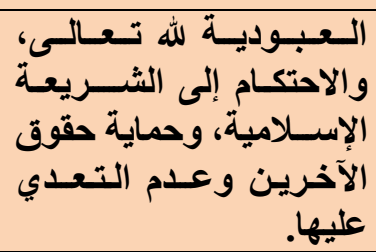 & 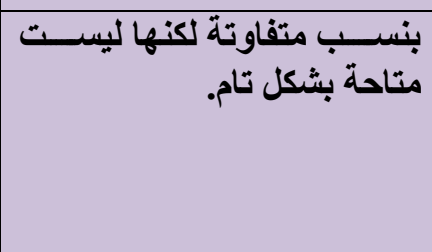 & 4 \\
\hline بالتو & التالبـداع، والأمـان، وحريـة & 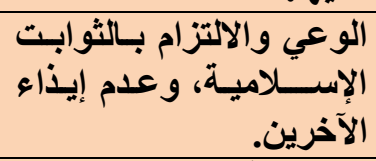 & ينة. & 5 \\
\hline ذاتيا. خلال تقزير المصــير & 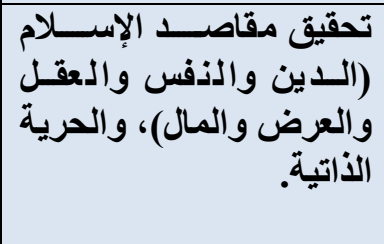 & 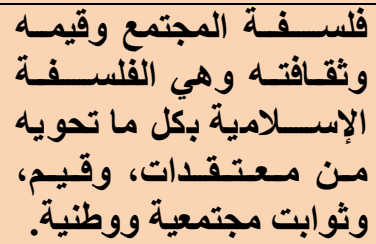 & 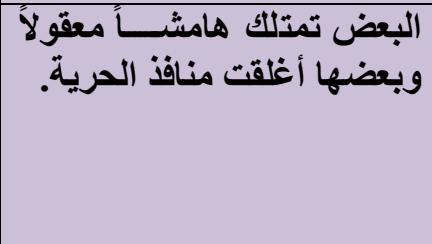 & 6 \\
\hline 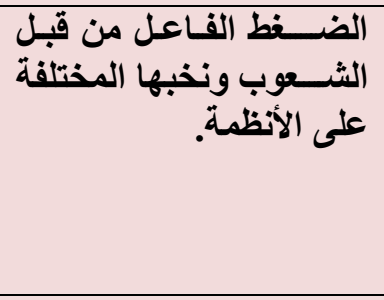 & 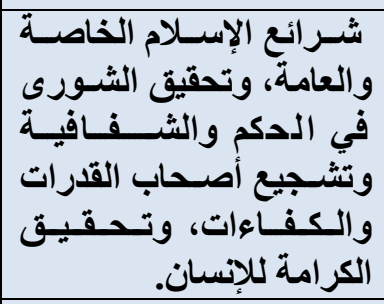 & الثريعة الإسلامية. & لآخـة ويختلف & 7 \\
\hline 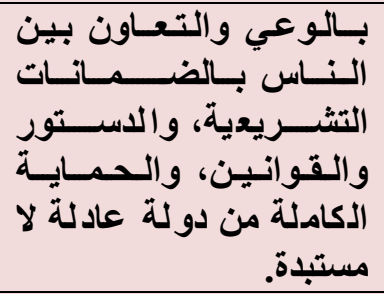 & 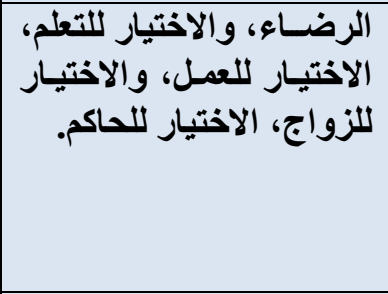 & النبوية. آلـ الكريم والســــــة & 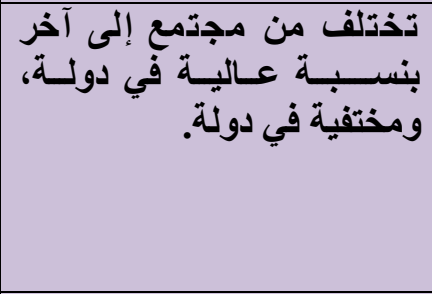 & 8 \\
\hline حكامـاومحكومين. التير تلزم الجميع & العالية. الإع، والإنتـاج، والهمـة & الفكرية. & $y$ & 9 \\
\hline 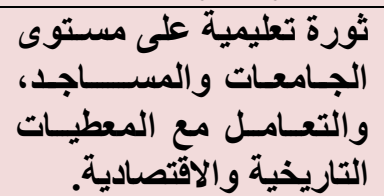 & الأمة. الأمان الشـــــي، نهضـة & 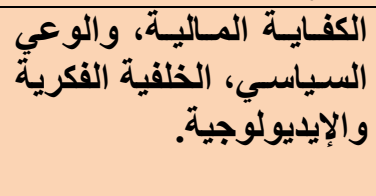 & 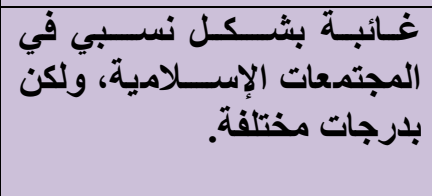 & 10 \\
\hline 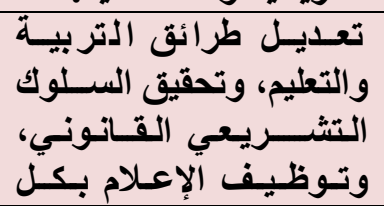 & 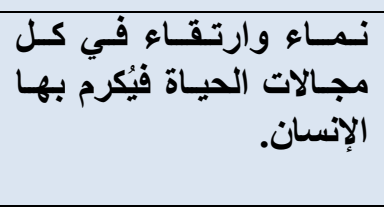 & القانونين وهـــايـاتـه، النظم & 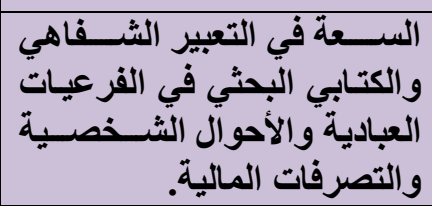 & 11 \\
\hline
\end{tabular}


واقع الحرية في الحضارات القديمة ومنطلقات ممارستها في المجتمعات الإسلامية المعاصرة

\begin{tabular}{|c|c|c|c|c|}
\hline مســتوياته لتعديل الخارطة & & & والإداري والضية في الثـــأن السـياسـي & \\
\hline 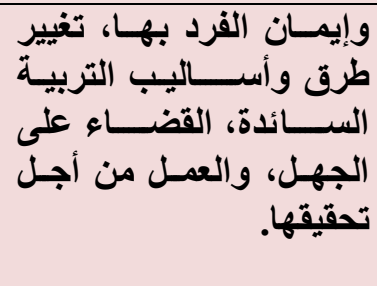 & 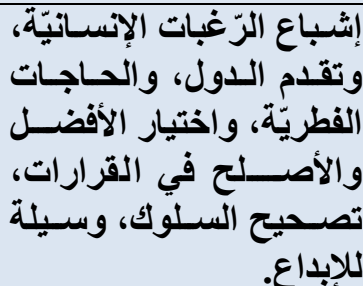 & البعد القردي والاعتمــاد على الجماعي. & والتفاب بشت بين حالة وأخِي الحرى. & 12 \\
\hline
\end{tabular}

\begin{tabular}{|c|c|c|c|c|c|c|}
\hline & $\mathbf{N}$ & Minimum & Maximum & المستوسطي & النسبة المئويةة & $\begin{array}{c}\text { Std. } \\
\text { Deviation }\end{array}$ \\
\hline 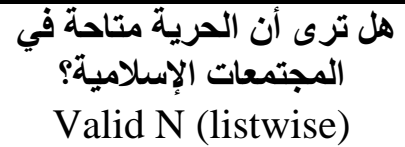 & $\begin{array}{l}12 \\
12\end{array}$ & 1.00 & 4.00 & 2.2500 & $\% 56$ & .86603 \\
\hline
\end{tabular}

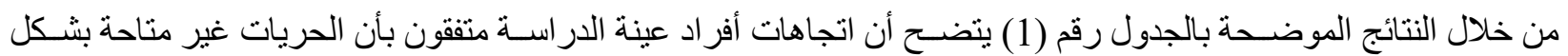

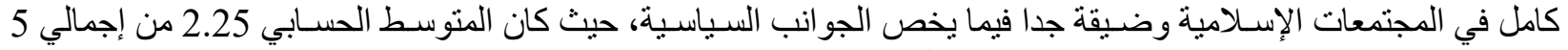

وبنسبة مو افقه 56\%، والتعات الاسي قيمة ضعيفة مقارنتها بالمتوسط الافتر اضي3.

\begin{tabular}{|c|c|c|c|c|c|}
\hline \multicolumn{6}{|c|}{ (جدول رقم:2) } \\
\hline & & التكرا & النسبة & $\begin{array}{c}\text { Valid } \\
\text { Percent }\end{array}$ & Cumulative Percent \\
\hline & & & $\%$ & & \\
\hline \multirow[t]{5}{*}{ Valid } & ضئيلة جدا & 2 & 16.7 & 16.7 & 16.7 \\
\hline & ضئيلة & 6 & 50.0 & 50.0 & 66.7 \\
\hline & متاحة نو عا ما & 3 & 25.0 & 25.0 & 91.7 \\
\hline & متاحة & 1 & 8.3 & 8.3 & 100.0 \\
\hline & Total & 12 & 100.0 & 100.0 & \\
\hline
\end{tabular}

أولا: توضيح الجدول

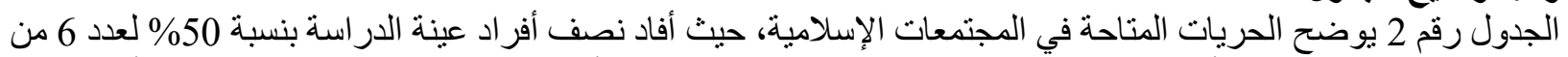

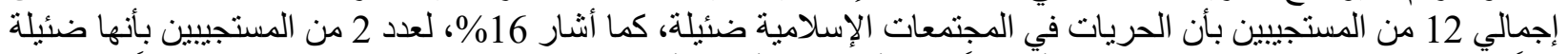

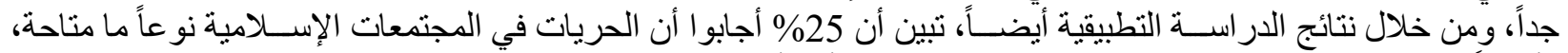

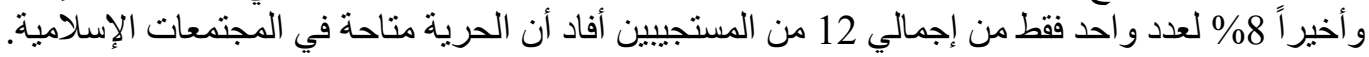

ثنانيا: تحليل الجدول من خلال إجابات وردود أجلود أفر اد عينة الدر اسة من الأكاديميين جاءت الإجابات تؤكد أن مساحة الحرية غير متاحة و غائبة وائة ومختفية

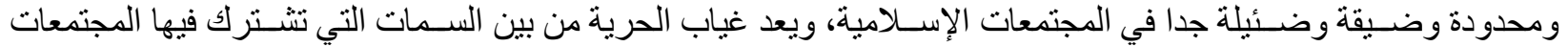

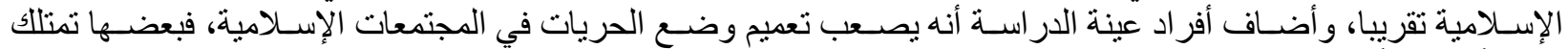

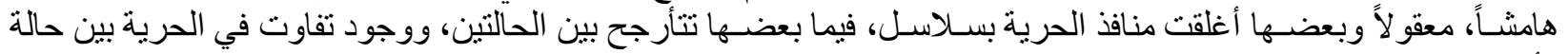

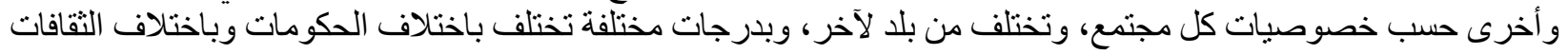

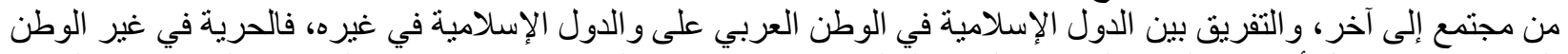

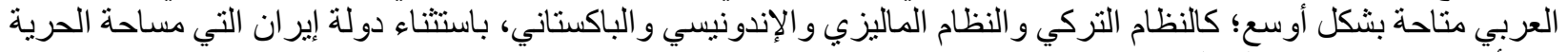
فيها أضيق ما يكون بين المسلمين.

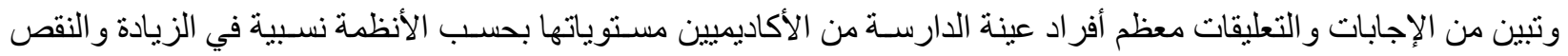

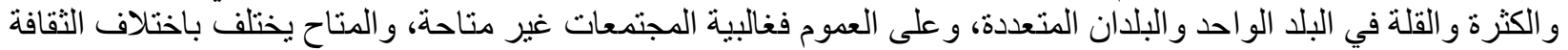

التي يتلقاها الأفر اد.د. 
Journal of Al-Tamaddun, Vol. 16 (2), 2021, 111-126

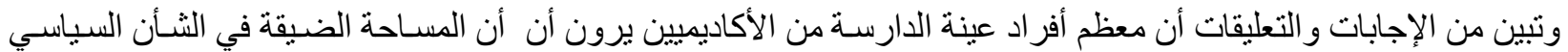

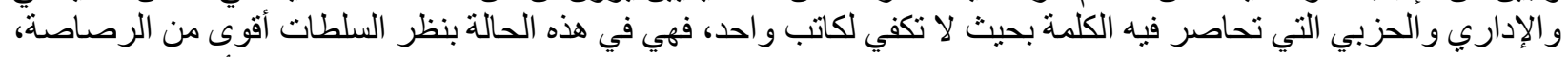

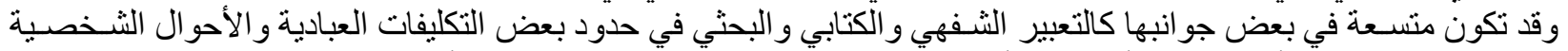

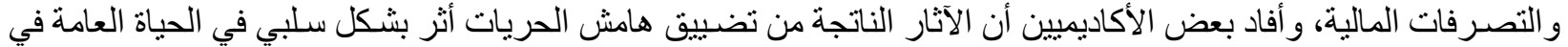

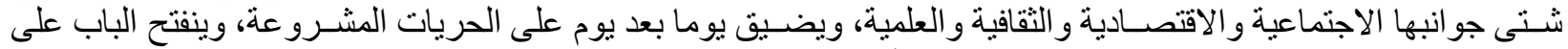
مصر اعيه للعابثين و المفسدين باسم الحريات و التقليد الأعور للحضارة الغربية التهاية المعاصرة.

السؤال الثاني: ماهي المنطلقات التي تعتمد عليها الحرية من وجهة نظرك؟ (3وك (جدول رقم:3) (3ن)

\begin{tabular}{|c|c|c|c|c|c|}
\hline & & التكرا & 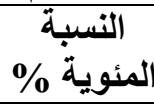 & $\begin{array}{c}\text { Valid } \\
\text { Percent }\end{array}$ & Cumulative Percent \\
\hline \multirow{7}{*}{$\begin{array}{r}\text { Vali } \\
\mathrm{d}\end{array}$} & الحرية و الكر امة و العدالة & 2 & 16.7 & 8.3 & 8.3 \\
\hline & الدين و الثو ابت الإسلامية & 4 & 33.3 & 33.3 & 41.7 \\
\hline & الوعي و الالتز ام بالثو ابت & 1 & 8.3 & 8.3 & 50.0 \\
\hline & الشر عية و القانونية & 1 & 8.3 & 8.3 & 58.3 \\
\hline & الدين والحرية و النظم & 2 & 16.7 & 16.7 & 75.0 \\
\hline & الو عي و الثو ابت الإسلامية & 2 & 16.7 & 16.7 & 100.0 \\
\hline & Total & 12 & 100.0 & 100.0 & \\
\hline
\end{tabular}

أولا: توضيح الجدول

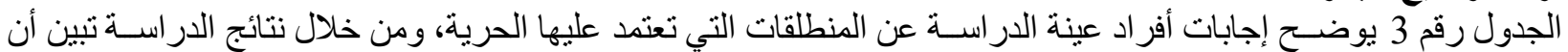

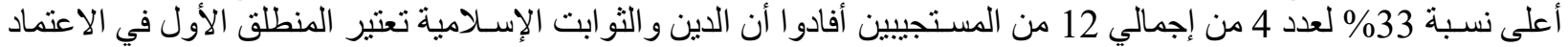

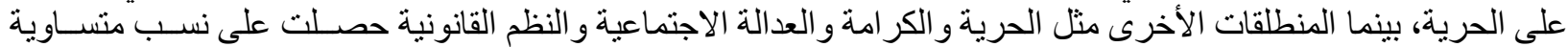

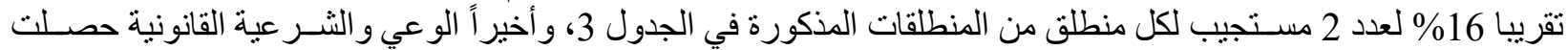
على أقل نسبة 8\% \% لعدد و احد من 12 مستجيب إجمالي أفر اد عينة الدراسة.

ثانيا: تحليل الجدول

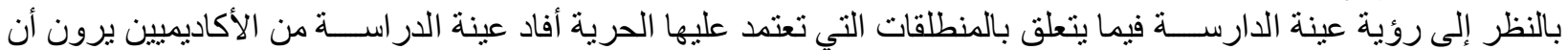

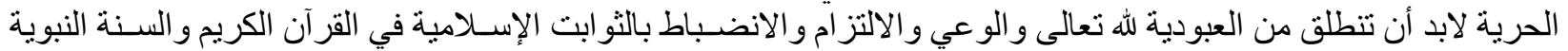

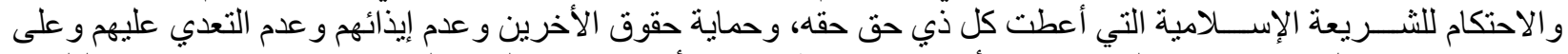

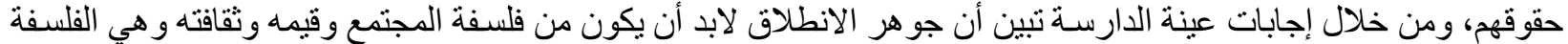

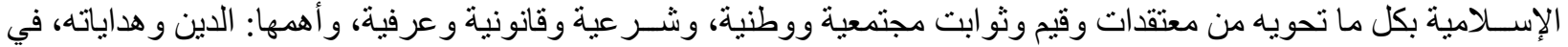

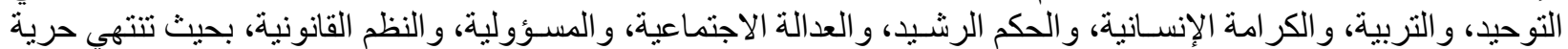
الفرد عندما تتصادم مع حقوق الآخرين.

كما يوجد رؤى مختلفة لعينة الدارسـة من خلال تحليل لإجابات منطلقات الحرية منها التأكيد على الكفاية المالية للفرد بما يتيح له

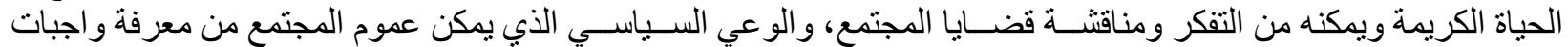

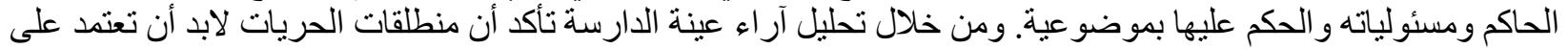

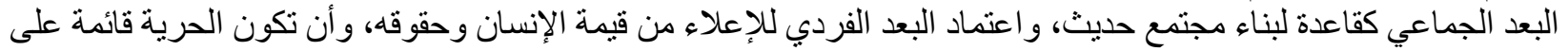
خلفية فكرية وإيديولوجية مشتركة بين طبقات المجنمع التي تمنع الصر اع الطائفي الذي يستغل غالبا من قبل الحكام الإن المستبدين.

السؤال الثالث: ما هي الفوائد التي ستحصل عليها من وجود الحرية؟ 
واقع الحرية في الحضارات القديمة ومنطلقات ممارستها في المجتمعات الإسلامية المعاصرة

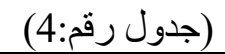

\begin{tabular}{|c|c|c|c|c|c|}
\hline & & 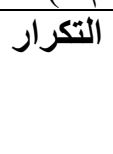 & $\begin{array}{c}\text { المئوية } \\
\text { \% }\end{array}$ & $\begin{array}{c}\text { Valid } \\
\text { Percent }\end{array}$ & Cumulative Percent \\
\hline \multirow{6}{*}{ Valid } & الإر ادة و الكر امة & 1 & 8.3 & 8.3 & 8.3 \\
\hline & العدالة و الاستقر ار و الأمن & 6 & 50.0 & 50.0 & 58.3 \\
\hline & مقاصد الثريعة الإسلامية & 2 & 16.7 & 16.7 & 75.0 \\
\hline & إنباع الحاجات و الر غبات & 1 & 8.3 & 8.3 & 83.3 \\
\hline & حرية التعبير و الإبداع & 2 & 16.7 & 16.7 & 100.0 \\
\hline & Total & 12 & 100.0 & 100.0 & \\
\hline
\end{tabular}

\section{أولا: توضيح الجدول}

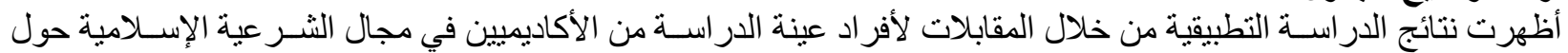

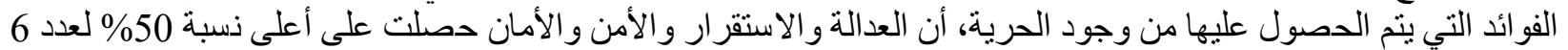

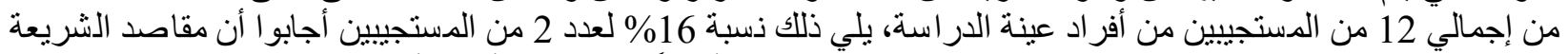

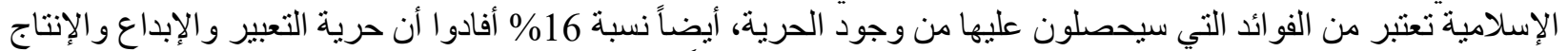

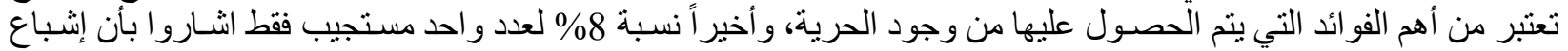

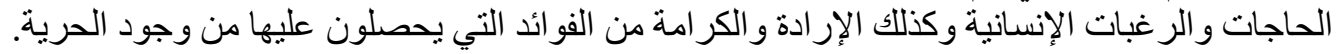

ثنانيا: تحليل الجدول

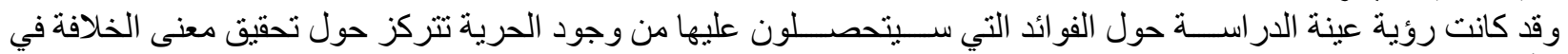

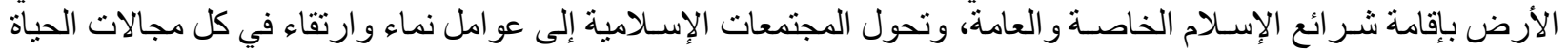

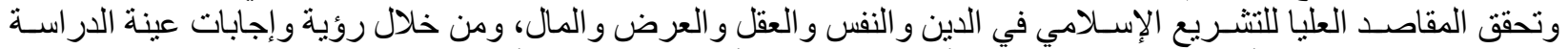

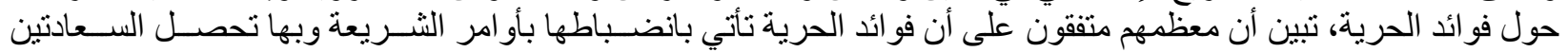
إرضاء الله تعالى وسعادة البشر.

و اعتبر بعض عينة الدر اسـة أن مناخ الحرية لابد أن يكون مع وجود أمور أخرى الثـورى في الحكم و الثـفافية والتبادل السـلمي

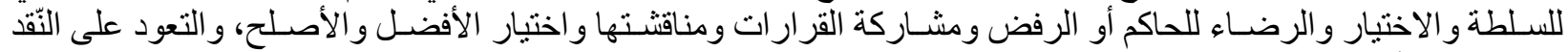

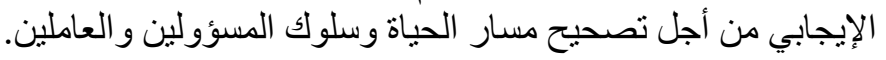

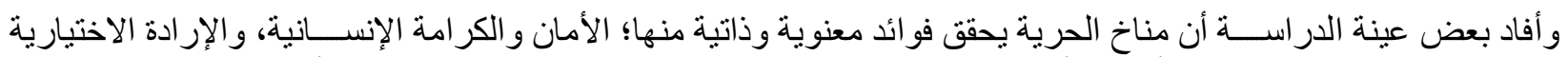

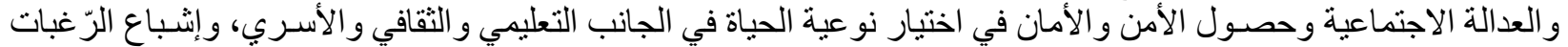

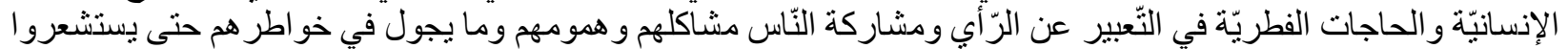

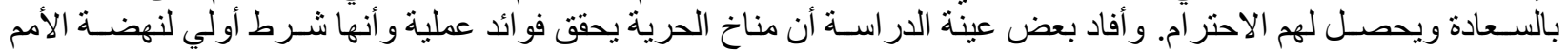

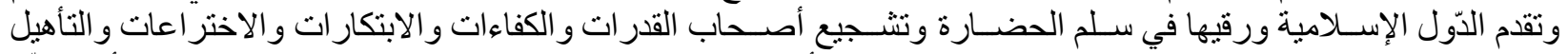

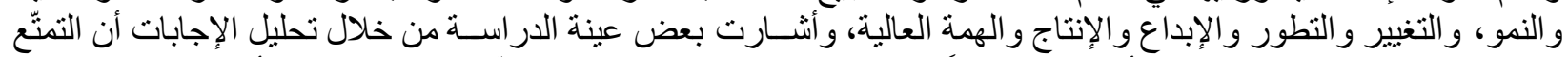

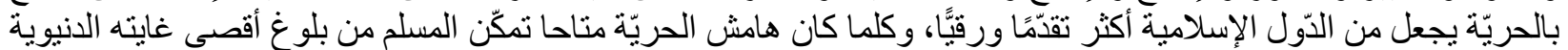
والأخروية.

السؤال الرابع: كيف يمكن تحقيق الحرية في المجتمعات الإسلامية؟

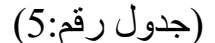

\begin{tabular}{|c|c|c|c|c|c|}
\hline & & التكرا & المئوية النسبة & $\begin{array}{c}\text { Valid } \\
\text { Percent }\end{array}$ & Cumulative Percent \\
\hline Vali & الوعي و التربية & 3 & 25.0 & 25.0 & 25.0 \\
\hline $\mathrm{d}$ & التربية و التعليم & 4 & 33.3 & 33.3 & 58.3 \\
\hline
\end{tabular}


Journal of Al-Tamaddun, Vol. 16 (2), 2021, 111-126

\begin{tabular}{|c|c|c|c|c|}
\hline العدل و المساو اة وتفعيل & 2 & 16.7 & 16.7 & 75.0 \\
\hline الحقوق و الو اجبات & 1 & 8.3 & 8.3 & 83.3 \\
\hline ضغوط الشعب وتوحيد & 2 & 16.7 & 16.7 & 100.0 \\
\hline Total & 12 & 100.0 & 100.0 & \\
\hline
\end{tabular}

أولا: توضيح الجدول

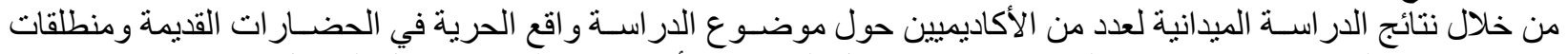

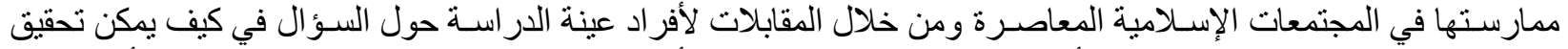

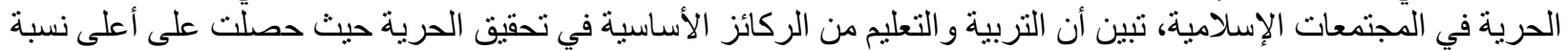

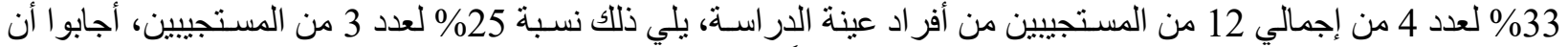

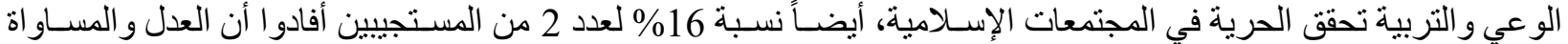

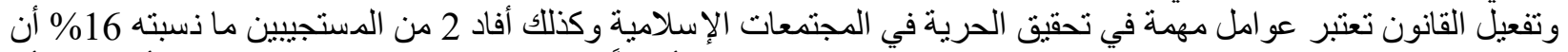

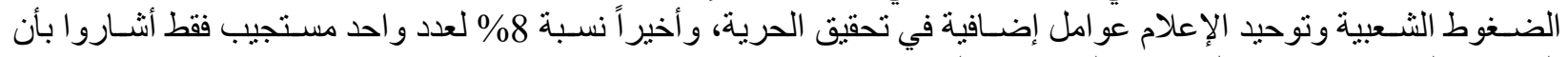
الحقوق و الواجبات من وسائل تحقيق الحرية في المجتمعات الإسلامية.

تثانيا: تحليل الجدول

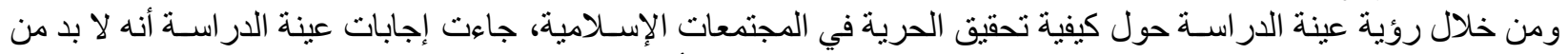

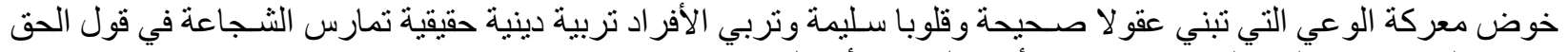
وتعتز بالذات؛ فلا يقبلون الدنبة و الاستعباد بأي حال من الأحوال.

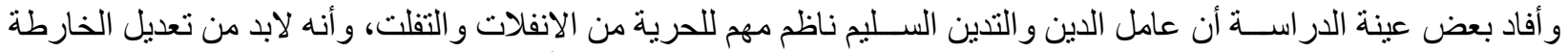

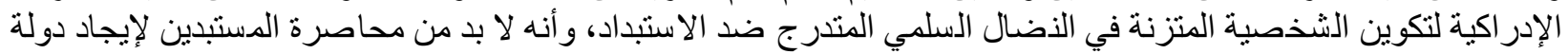

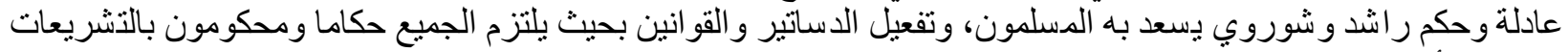
النافذة والأعمال النافعة.

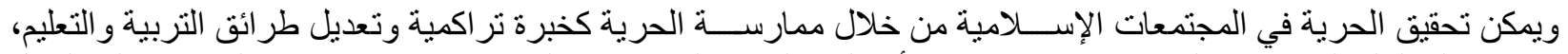

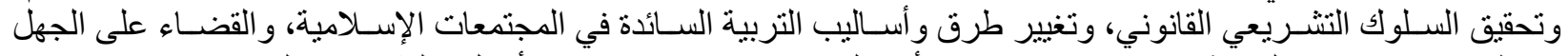

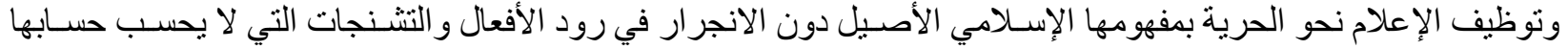

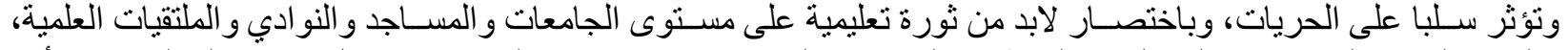

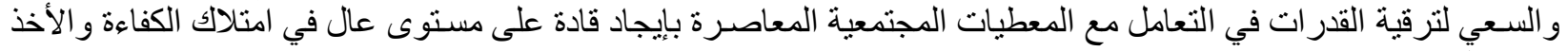

بزمام المبادرة.

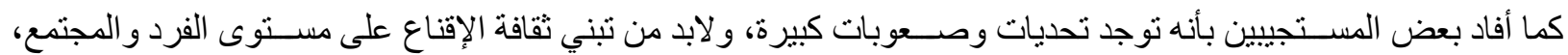

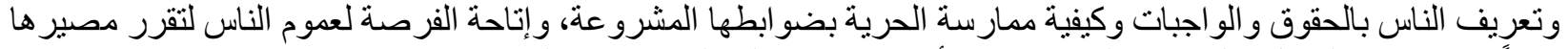
بعيداً عن وصاية الدخيل و الخارج و الوقوف بحزم أمام الاعتداء على الحريات في المجنمعات الإسلامية.

الخلاصة وأهم النتائج

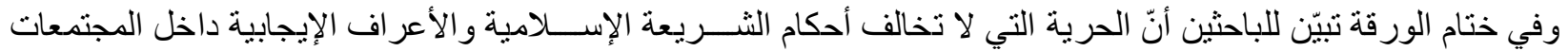

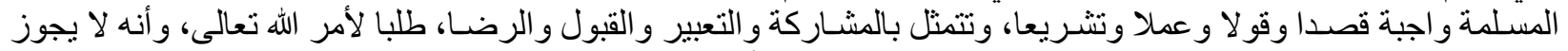

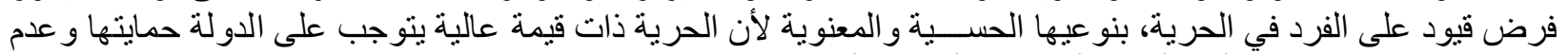

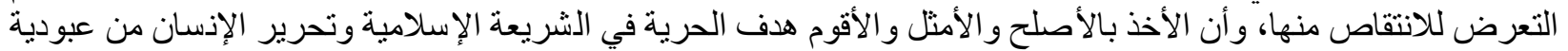

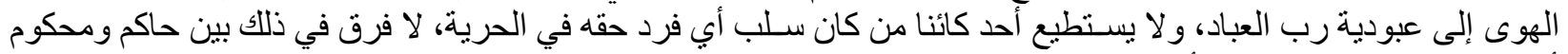

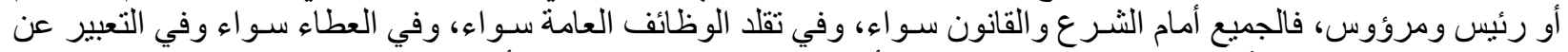

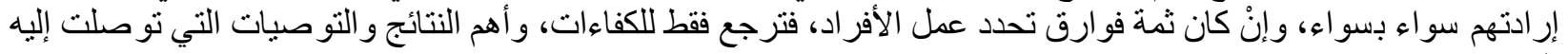

الار اسة: 
واقع الحرية في الحضارات القيمة ومنطلقات ممارستها في المجتمعات الإسلامية المعاصرة

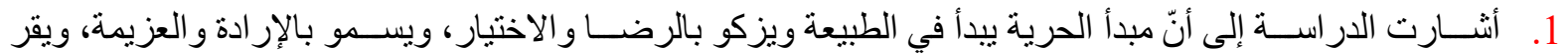

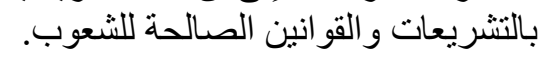

2. لاحظت الدر اسة اضطر اب ممار سات الحرية في الدضار ات السابقة، بسبب إخضاع الشعوب لسلطة الفرد المطلقة وتحريف الموروث الديني.

3. أكدت الدر اسة على اعتر افت الإسلام بحرية الإنسان؛ بضبطها على أساس الدين و المصلحة المعتبرة بميزان الشريعة الإسلامية العادلة.

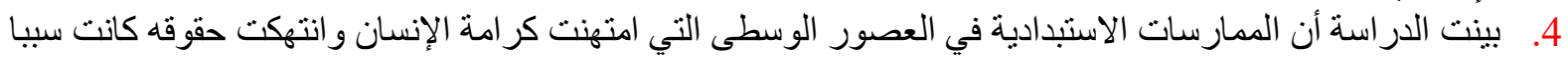

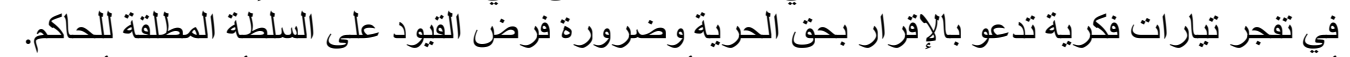

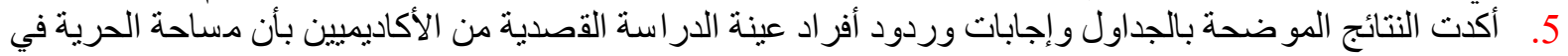

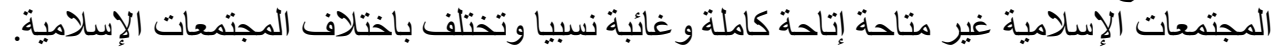

التوصيات: بوصي الباحثان بالآتي:

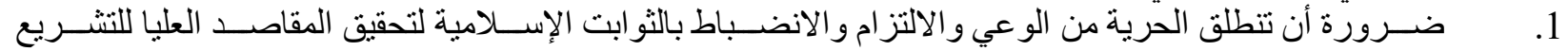

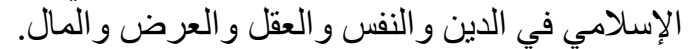

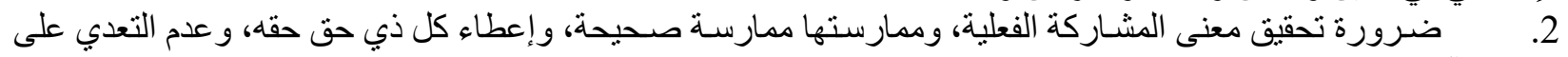
حقوق الآخرين.

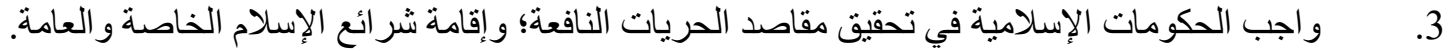

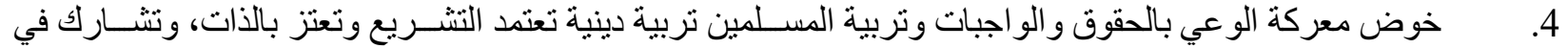
تصحيح الو اقع و لا تقبل غير الحق. 


\section{References}

'Abd al-Mun'im Ahmad (2002), Mabda' al-Masāwah fi al-Islām, Alexandria: al-Maktab al-'Arabi alHadīth.

'Ābidīn, Hasan Ahmad (n.d.), Huqūq al-Insān wa Wājibātuhu fi al-Qur'ān, Makkah: Maṭba'ah Rābițah al'Ālam al-Islāmi.

'Arif, Nāsir Muhammad (1981/1406H), Nazariyyāt al-Tanmiyyah al-Siyāsiyyah al-Mu 'āsirah fi Daw' alManzūr al-Hadāri al-Islāmi, USA: al-Ma'had al-'Ālami li al-Fikr al-Islāmi.

'Awdah, 'Abd al-Qādir (1981/1401H), al-Islām wa Awdā'una al-Siyāsiyyah, Beirut: Mu'assasah alRisālah.

'Ittiyyah Muhammad Ahmad (n.d.), Huqūq al-Insān bayna Had'y al-Rahmān wa Ijtihād al-Insān, Kuwait: Maktabah al-'Athīr.

'Uwayyid, ‘Adnān, al-Hurriyyah Wa'yu al-Ḍarūrah, http://www.almothaqaf.'om/a/b12-1/929915.

Abū Zahrah, Muhammad (1970), al-Takāful al-Ijtimā' 'i fi al-Islām, Egypt: Dār al-Fikr al-'Arabi.

Abū Zahrah, Muhammad (1981), al-Mujtama 'al-Insāni fā al-Islām, Saudi Arabiya: al-Dār al-Sa'udiyyah li al-Nashr wa al-Tawzi'.

al-'Amri, Sulțān ibn 'Abd al-Raḥmān (2013), Fadā'āt al-Hurriyyah, Cairo: al-Markaz al-'Arabi li alDirāsāt al-Insāniyyah.

al-Bayāti, Mun̄̄r Hamīd (1994), al-Nizām al-Siyāsī al-Islāmī Muqārana bi al-Dawlah al-Qānūniyyah, Jordan: Dār al-Bashr.

al-Darini, Fatḥi (1982), Khasāis al-Tashri al-Islāmi fi al-Siyāsah wa al-Hukm, Beirut: Muassasah alRisālah.

al-Ghanushi, Rāshid. al-Hurriyyah fi al-Islām. Mawqi https://www.aljazeera.net/knowledgegate/opinions/2007/10/11/\%D8\%A7\%D9\%84\%D8\%AD\%D8\%B1 $\% \mathrm{D} 9 \% 8 \mathrm{~A} \% \mathrm{D} 8 \% \mathrm{~A} 9-\% \mathrm{D} 9 \% 81 \% \mathrm{D} 9 \% 8 \mathrm{~A}-$ \%D8\%A7\%D9\%84\%D8\%A5\%D8\%B3\%D9\%84\%D8\%A7\%D9\%85.

al-Hamadi, ‘Abd al-‘Aziz (n.d.), Mafāhim al-Hurriyyah wa Tatbiqātuha, Jeddah: Markaz al-Ta’ṣīl li alDirāsāt wa al-Buhūth.

Al-Ḥaq̄il, Sulaymān (n.d.), Huqūqq al-Insān fì al-Islām wa al-Radd 'alā al-Shubhāt al-Muthārah hạwluhu, Riyadh: n.p.

al-Jabūri, Sājir Nāsir Hamd (2005), Huqūu al-Insān al-Siyāsiyyah fi al-Islām wa al-Nuzum al-'Ālamiyyah, Beirut: Dār al-Kutub al-'Ilmiyyah.

al-Jurjāni, 'Alā ibn Muhammad ibn 'Alī (1405H), al-Ta 'rīfāt Taḥqīq. Ibrahim al-Abyāri, Beirut: Dār alKitab al-'Arabi.

al-Manzumah al-Dawliyyah li Huquq al-Insān wa al-Qānun al-Dawli, al-Haq Qadim wa Wathā'iq Huquq al-Insān fi al-Thaqāfah al-Islamiyyah, Tahlil wa Taqdim Ghanim Jawwad. http://www.iohril.org/news.php?extend.304.6. 
واقع الحرية في الحضارات القديمة ومنطلقات ممارستها في المجتمعات الإسلامية المعاصرة

al-Nadwah al-'Ālamiyyah li Shabāb al-Islāmi (1420H), al-Mawsu'ah al-Muyassarah fi al- 'Adyān wa alMadhāhib wa al- 'Ahzā̄b al-Mu'āsirah, Ishrāf wa Takhtit wa Murāji'ah Mani' ibn Hammad al-Juhāni, Arab Saudi: Dār al-Nadwah al-’Ālamiyyah li al-Tibā'ah wa al-Nashr wa al-Tawzi'.

al-Raqib, Sālih (2004/1425H), Wāqi 'una al-Mu'āsir wa al-Ghazw al-Fikri. Palestine: n.p.

al-Sharīf, Ahmad Ibrāhim (n.d.), Makkah wa al-Madīnah fi al-Jāhiliyyah wa 'Ahd al-Rasul șalla Allah 'alayh wa sallam, n.p.: Dār al-Fikr al-'Arabi.

al-Shihābi, Ibrāhim (1990), al-Qur'ān Harrar al-Insān, Tripoli: Manshūrāt Jam'iyyah al-Da'wah alIslāmiyyah al-'Ālamiyyah.

al-Ṭabarī, Muhammad ibn Jarīr (1387H), Tārikh al-Ṭabarī wa al-Rusul wa al-Mulūk, Beirut: Dār al-Turāth.

al-Zuhayli, Wahbah (2000/1421H), Haqq al-Huriyyah fì al-'Alam, Dimashq: Dār al-Fikr.

Badawi, Tharwāt (1970), Ușūl al-Fikr al-Siyāsī wa al-Naẓariyyāt wa al-Madhāhib al-Siyāsiyyah al-Kubrā, Kaherah: Dār al-Nahḍah al-'Arabiyyah.

Badawi, Tharwāt (1986), al-Nuẓum al-Siyāsiyyah, Cairo: Dār al-Nahḍah al-’Arabiyyah.

Ghazwi, Muhammad Salim Muhammad (n.d.), al-Hurriyyāt al-'Ammah fi al-Islām ma'a al-Muqāranah bi al-Mabādi' al-Dusturiyyah al-Gharbiyyah wa al-Maksiyyah, Alexandria: Mu'assasah Shihāb alJāmi'iyyah.

I'lān al-Qāhirah hawla Huquq al-Insān fi al-Islām, Munazzamah Mu'tamar al-'Ālam al-Islāmi, http://hrlibrary.umn.edu/arab/a004.html.

Ibn Hishām (1411H), al-Sīrah al-Nabawiyyah, Taḥqīq. Ṭaha 'Abd al-Ra'ūf Sa'd, Beirut: Dār al-J̄̄l.

Ibn Manzūur, Muhammad ibn Mukarram (1414H), Lisān al- 'Arab, Beirut: Dār al-Șādir.

Jawwād 'Ali (2001), al-Mufașsal fì Tārīkh al-'Arabī qabla al-Islām, n.p.: Dār al-Saqi.

Majdūb, Muhammad Sa‘īì (1986), al-Hurriyyāt al-’Ammah Huqūuq al-Insān, Lebanon: Jarrous Press.

Rābi', Munīb Muhammad (1988), Damānāt al-Hurriyyah bayna Wāqi'iyyah al-Islām wa Falsafah alDimuqratiyyah, Riyadh: Maktabah al-Ma‘ārif.

Sabbarini, Ghāzi Ḥasan (1994), al-Wajīz fi Huqūq al-Insān wa Hurriyyātihi al-'Asāsiyyah, Amman: Maktabah Dār al-Thaqāfah li al-Nashr wa al-Tawzi'.

Sarhān, 'Abd al-Azīz Muhammad (1987), al-Itār al-Qānuni li Huqūq al-Insān fi al-Qānun al-Dawli Dirāsah Muqāranah bi al-Shari' 'ah al-Islāmiyyah, n.p.: Dār al-Hanā li al-Tibā'ah.

Shabl, Fu'ād Muhammad (1974), al-Fikr al-Siyāsi, n.p.: al-Hay'ah al-Mișriyyah al-'Ammah li al-Kitāb.

Ṭāhun, Ahmad Rashshād (1998), Hurriyyah al- 'Aqīdah fi al-Sharī'ah al-Islāmiyyah, Cairo: Dār Itrāk li alNashr wa al-Tawzi'.

UN, al-I'lān al-'Ālami li Huquq al-Insān, https://www.un.org/ar/universal-de'laration-humanrights/index.html. 
Journal of Al-Tamaddun, Vol. 16 (2), 2021, 111-126

UN, Huquq al-Insān, Maktab al-Mufawwad al-Sāmi: al-Sukuk al-'Ālami li Huquq al-Insān, https://www.oh'hr.org/ar/ProfessionalInterest/Pages/UniversalHumanRightsInstruments.aspx.

Web al-Anbā' Takla Hiymanūt. https://st-takla.org/Bibles/BibleSear'h/showVerses.php?book=5\&'hapter. 